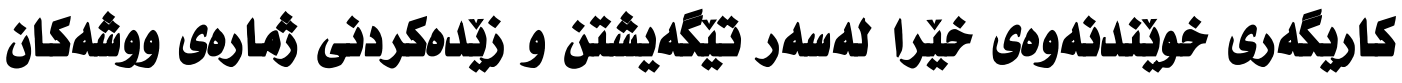

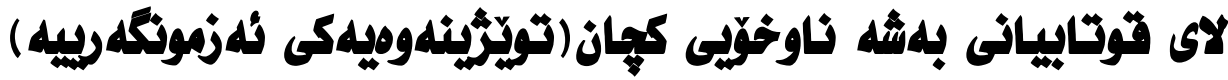

\section{مؤيل اسماعيل جرجيسن}

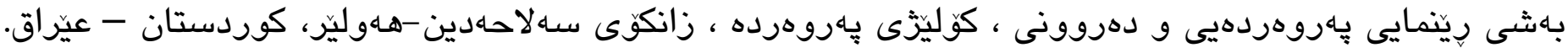
moaid.jarjis@su.edu.krd :يمهيل

بازيان ستار غفور

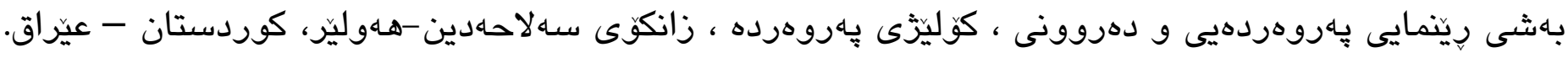
كيمهيل: gazyanbarznji10@gmail.com

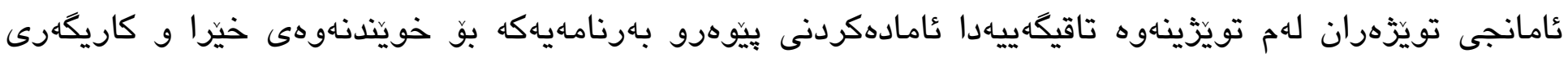

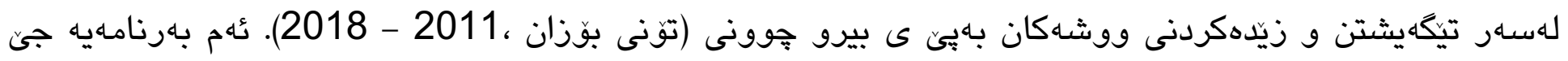

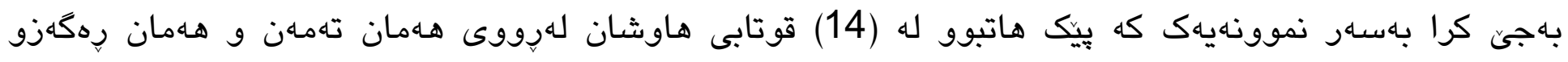

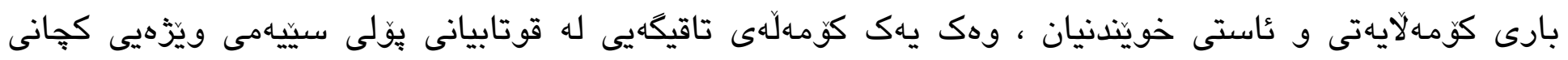

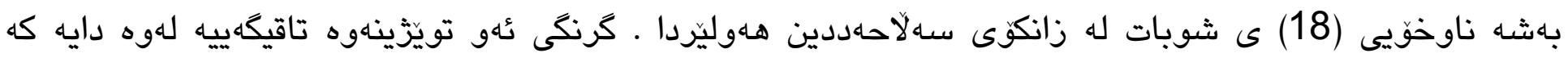

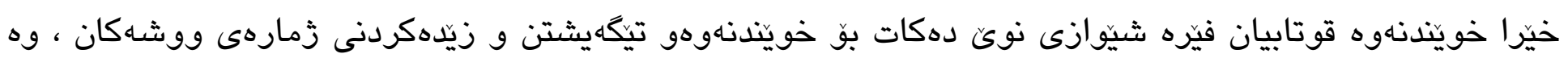

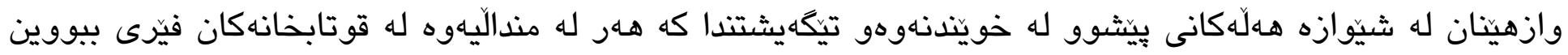

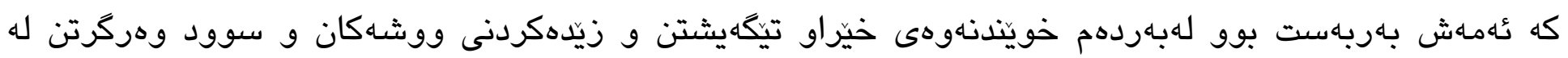

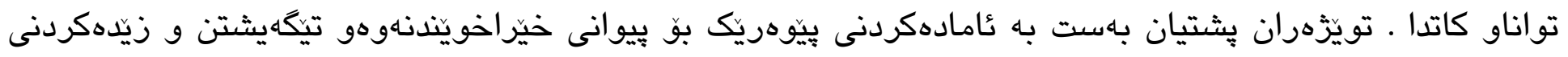

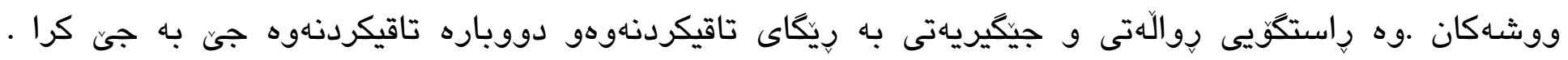

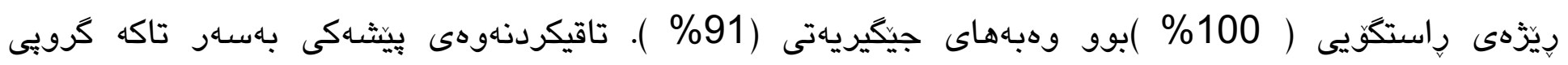

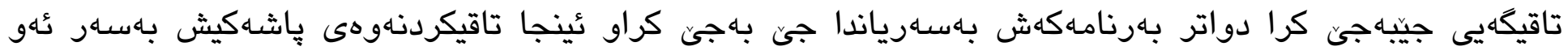

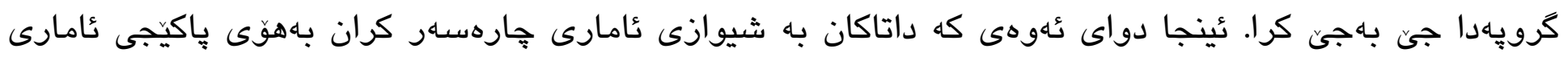




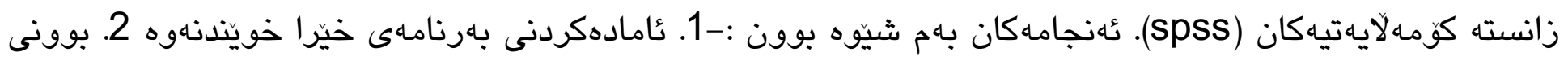

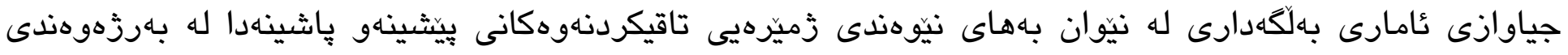

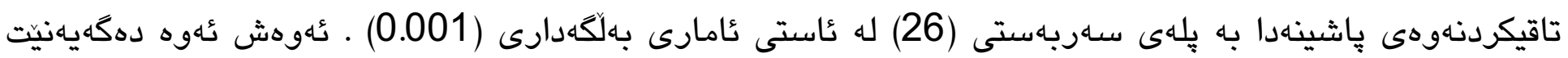

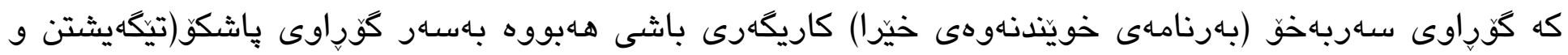

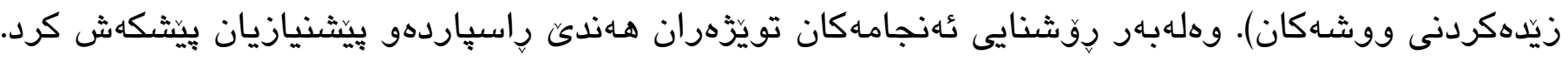

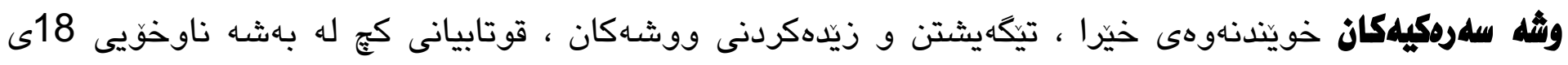
شوبات .

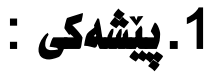

كرنكه كه ئهوه بزانين كه خوينّناهوه يشت بهزمان دهبهتيّت و بهاهنها بِروّسهيهى بينين نيه. وه قسهكردن

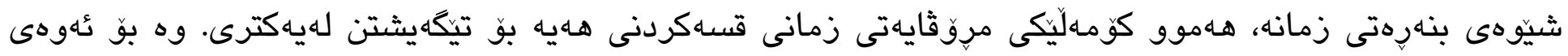

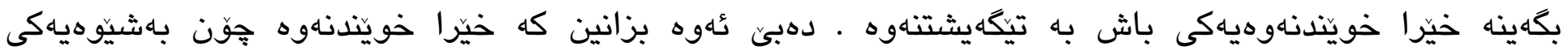

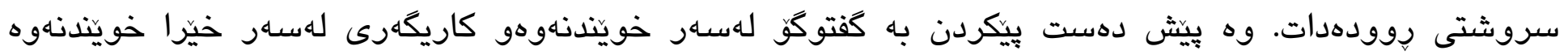

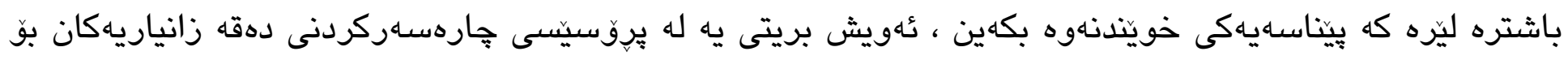

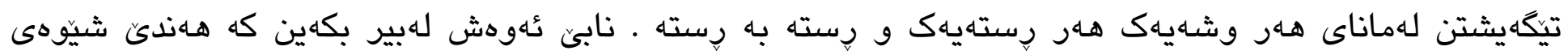

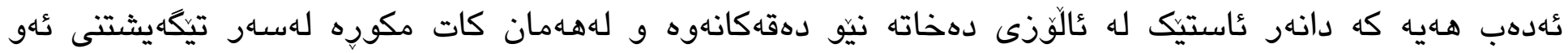

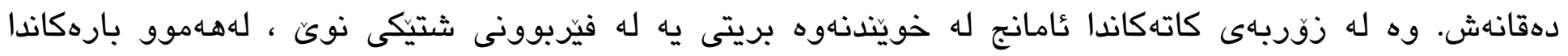

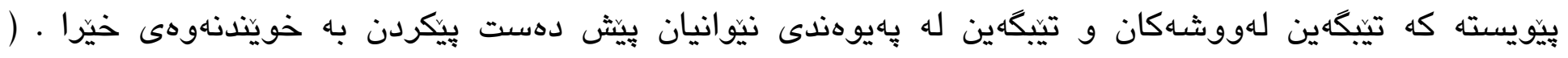
Rayner, \& et al,2016,p: 5

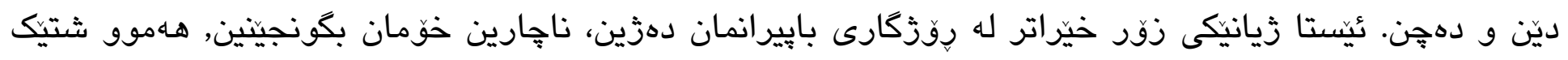

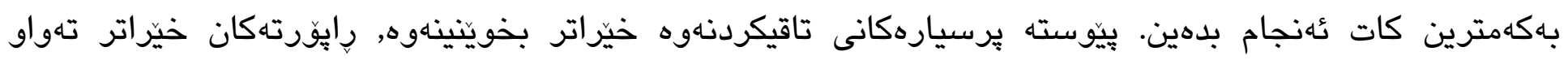

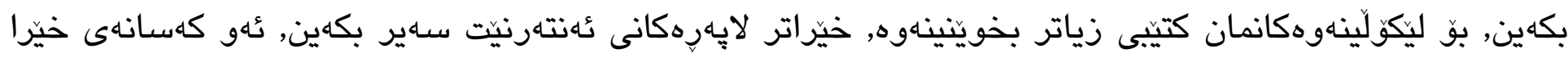

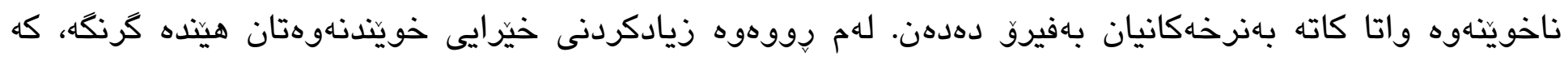

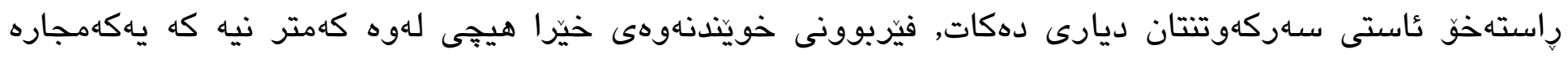

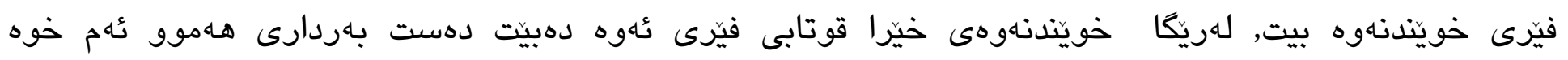

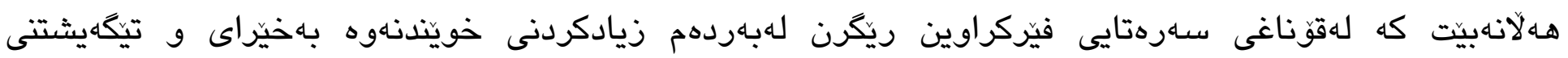

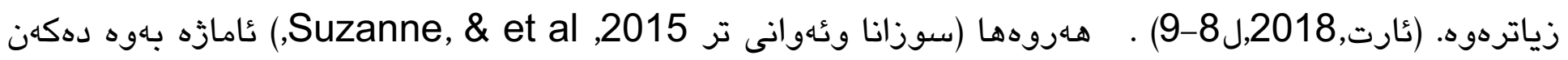

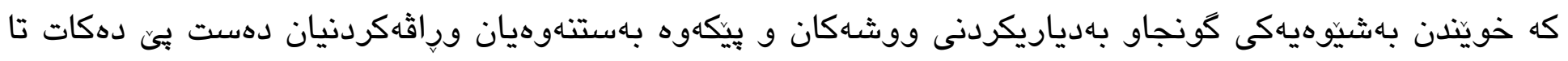

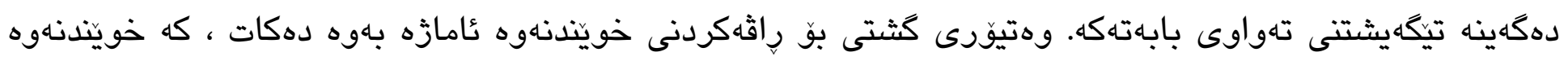




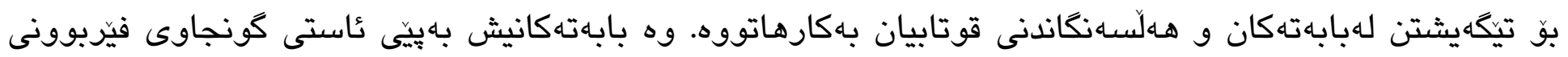

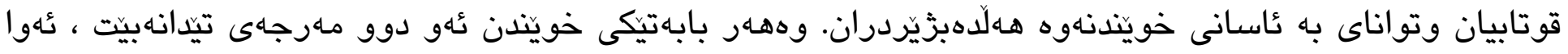

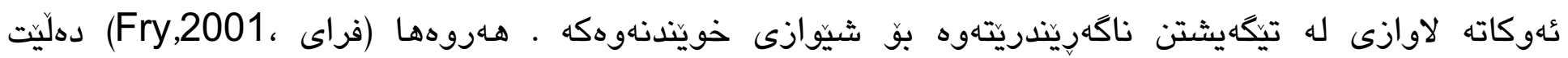

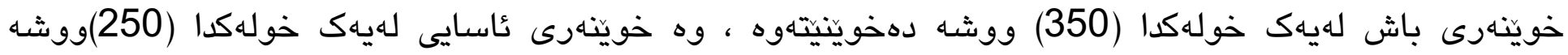

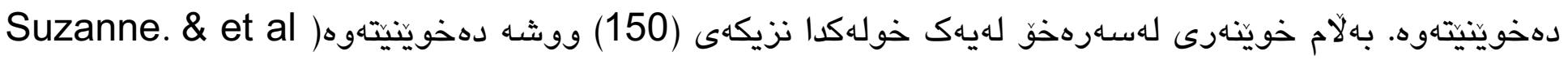

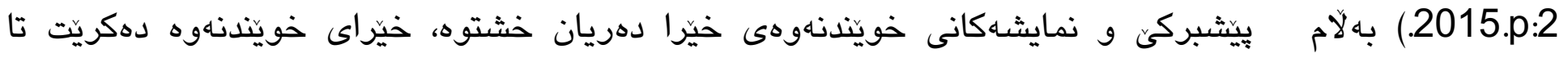

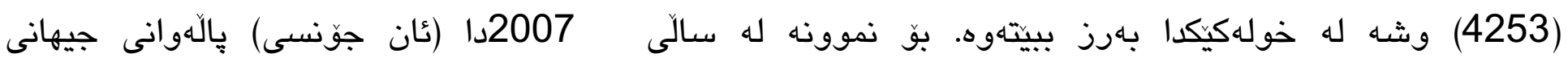
خويندنهوهى خيّرا له كتيبخانهيهكى لهندهن له بهرجاوى

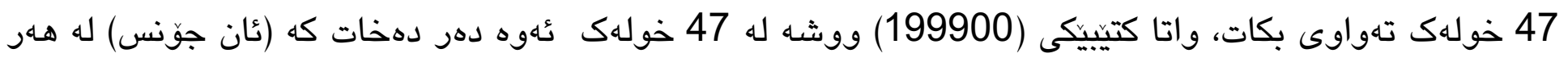

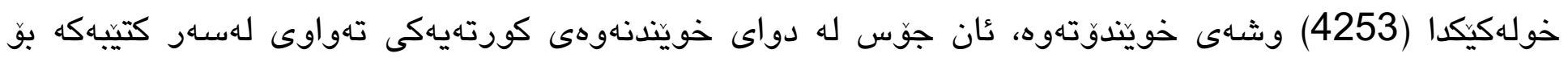

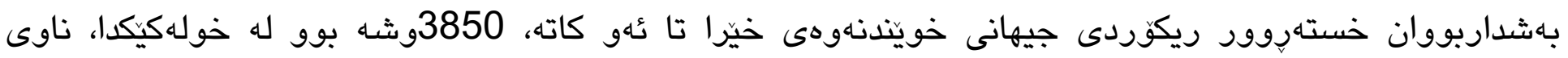

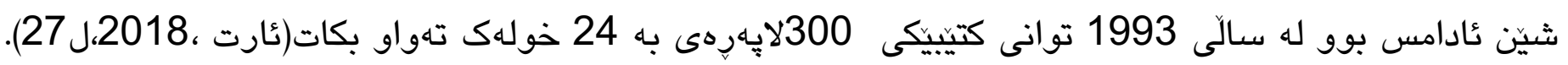

\section{1}

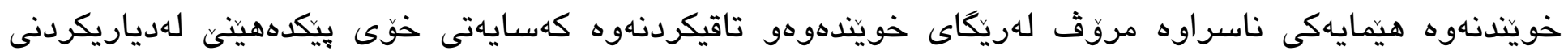

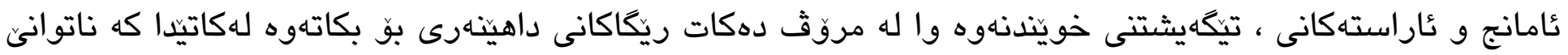

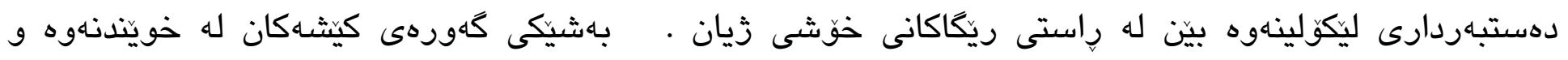

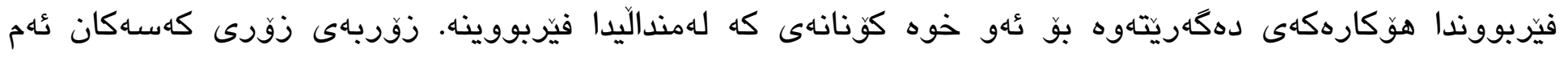

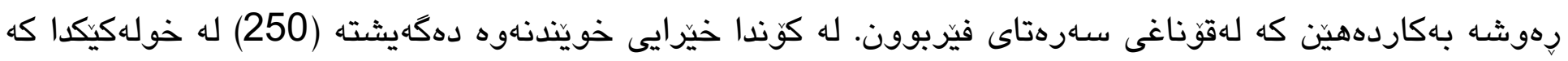

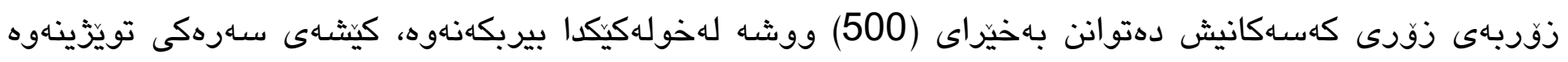

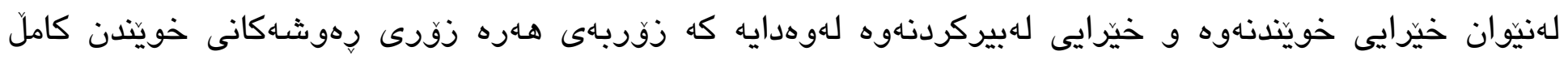

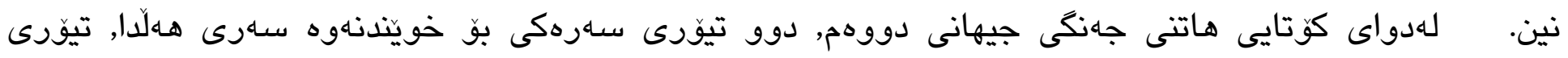

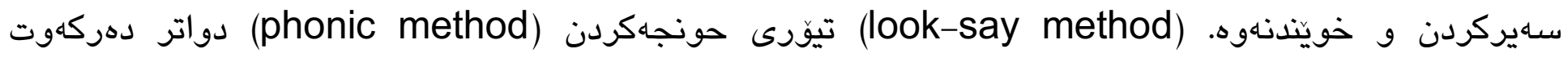

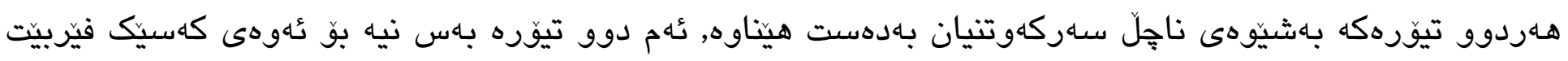

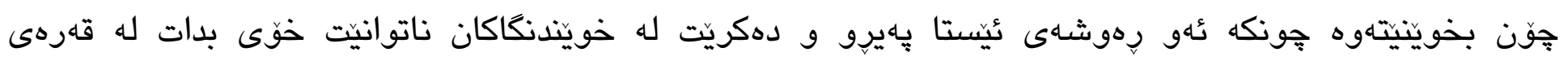

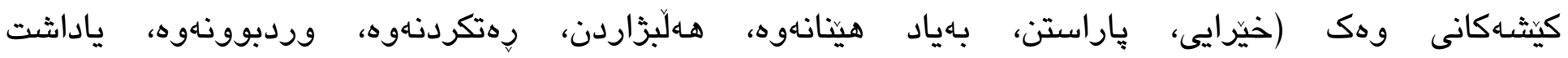

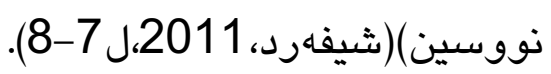

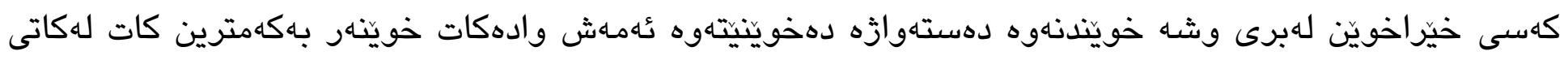

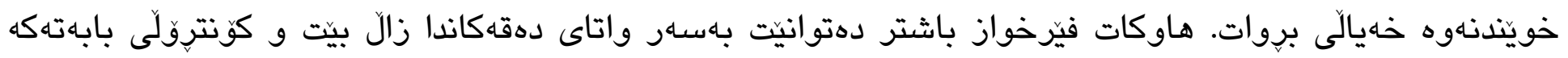




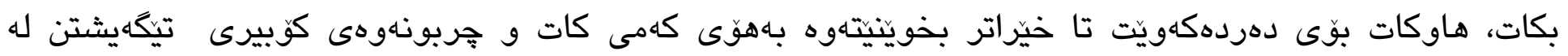

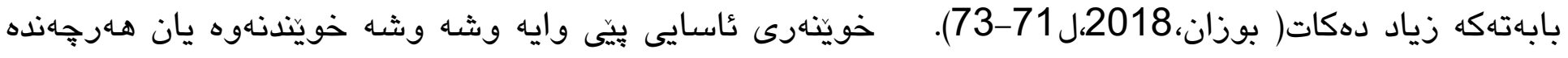

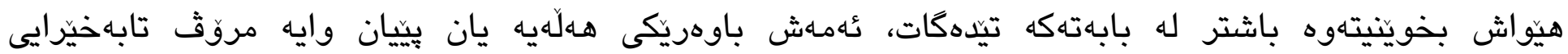
بخوينيتهوه تهركيزى كهمدهيتاهوه هاوكات لهم باوهرهدان ئهتهمه مروق بتوانيت بهخيّرايي ( 500) وثـه

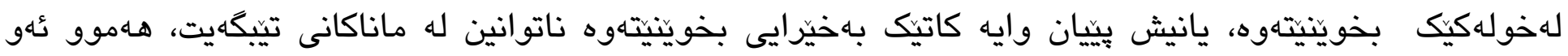

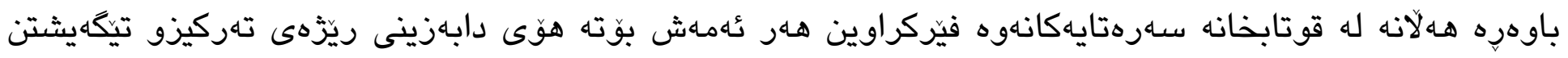

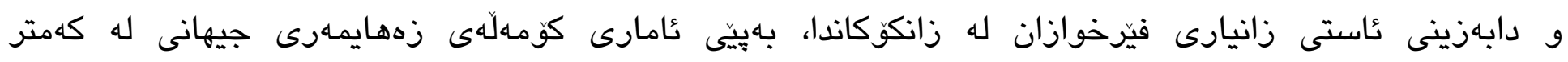

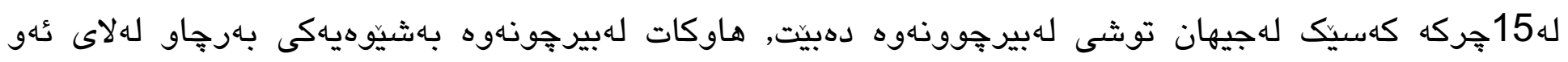

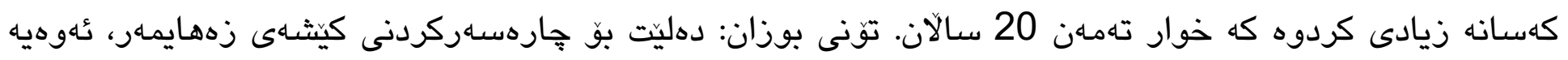

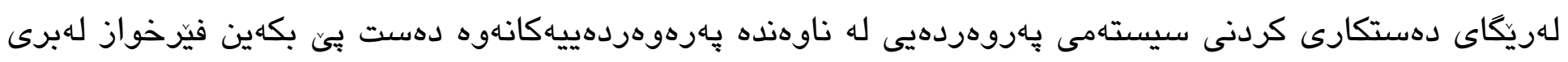

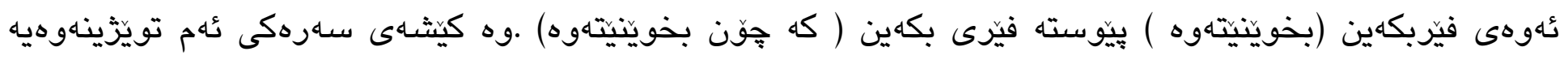

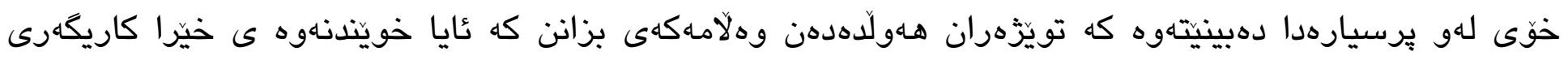

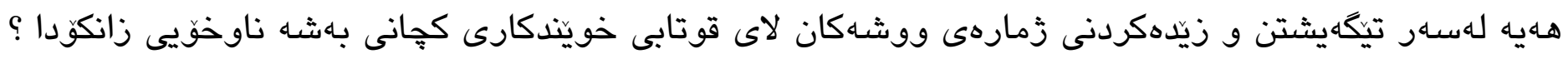

\section{1}

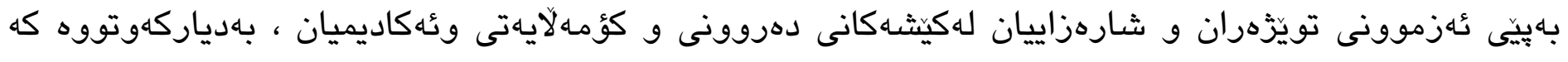

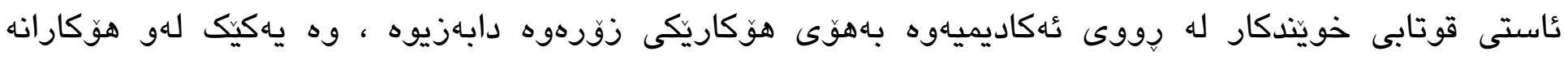

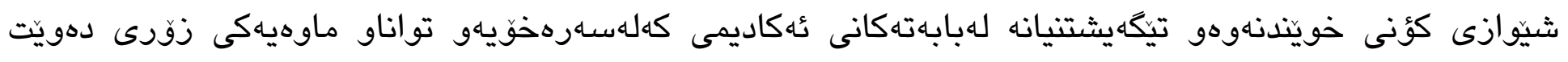

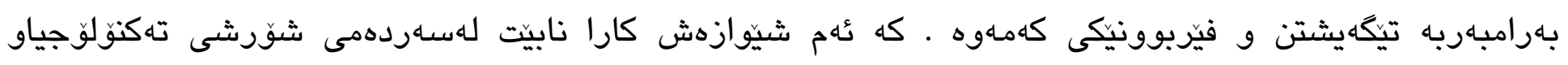

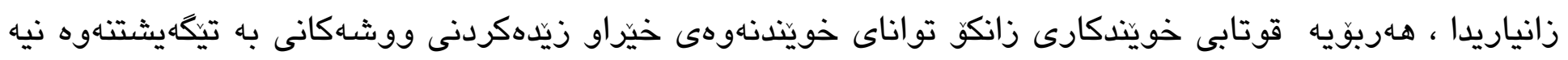
يان كهمه. بهراى تويّزهران كرنكى تويَّزينهوهكه بهم شيّوهيه ديارى دهكريت :

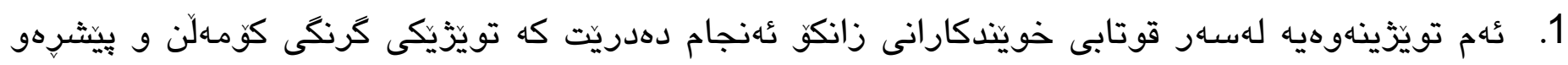

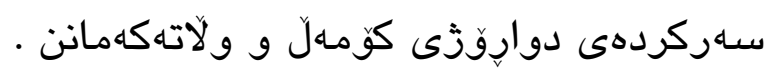

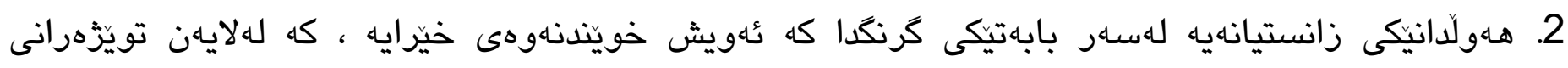

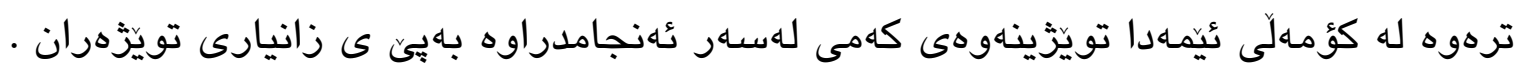

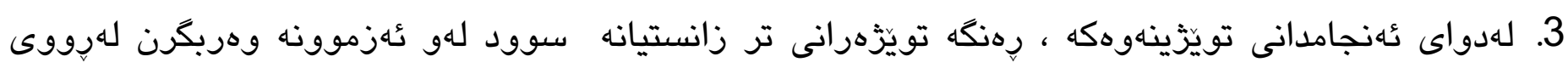

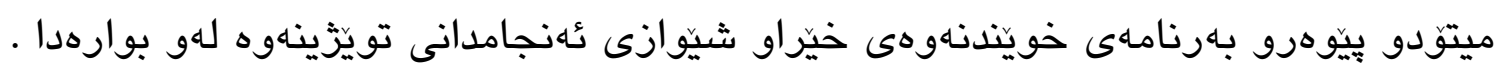

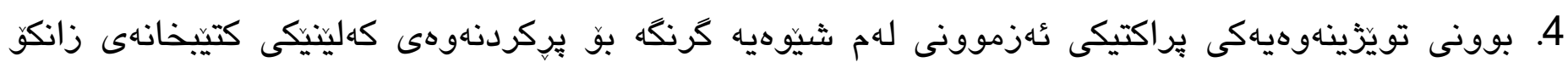
بهامـبهستى سوود وهركرتن لهو تويَزّينهوهيه. 
5. بهسوود وهركرتن لهئهنجامى ئه تويَزينهوهيه رِنكه بتوانريتّ بهرنامهيهكى زانستيانه دابنريت للالايهن

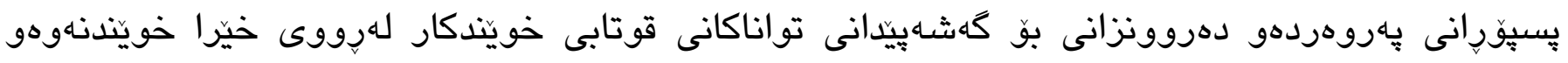

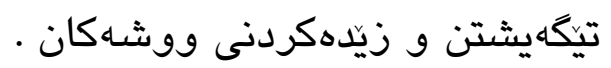

\section{1}

1. جياوازى نامارى بهلكَهدارى هاهيه له نيّوان نمرهى نيّوهندى زميّرهيى تاقيكردنهوهى يِيشينه و نمرهى نيّهندى

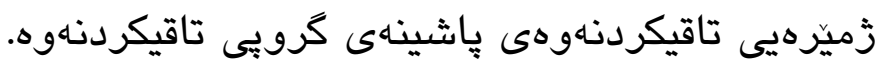

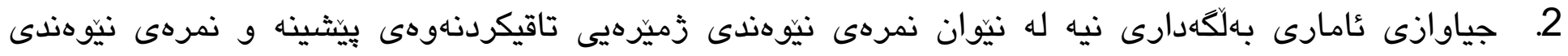
زميّرديى تاقيكردنهوهى بِاشينهى كرويى تاقيكردنهوه.

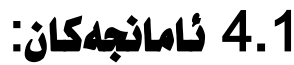

1 - ئامادهردنى بهرنامهيهك لهسهر بنهماى بو جوونهكانى(بوزان-1971-،2018)لهسهر خويَندنهوهى خيّرا و تيكّهيشتن و زيّدهردنى زمارهى وشهان

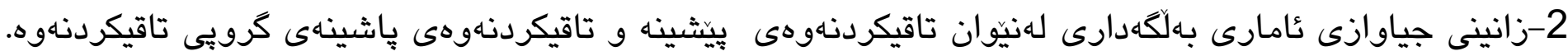

5.1

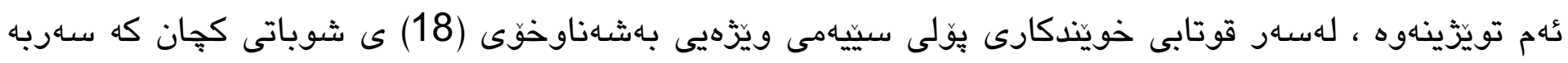

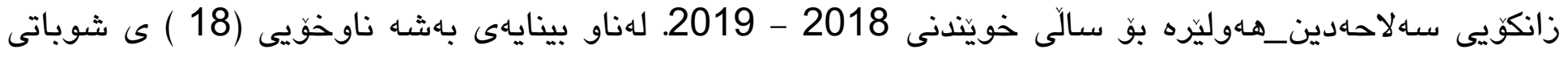

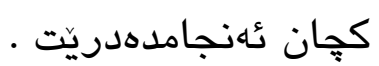

\section{1}

أ. خويَندنهوهى خيّرا : (1)

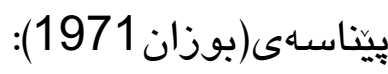

رهوهنديكّه لايهنهانى دهرهكى و ناوهكى تيدا دهكهنه هاوسانكى, بهتايبهتيش ناسين و تيك بهستن و بهاياد سياردن

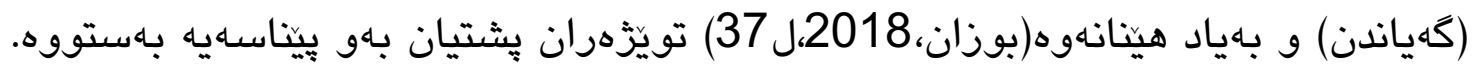


خويندنهوهى خيرا بريتيه له شارهزا بوون به كيثاه زهحمهتيهكانى خويندنهوه و تيكست تيكاهيشتن و بهكارهينانى

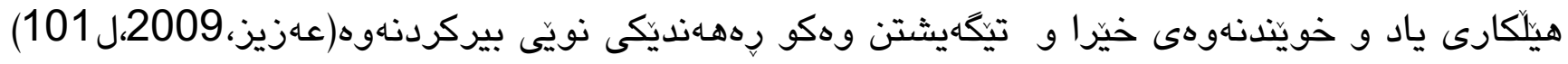

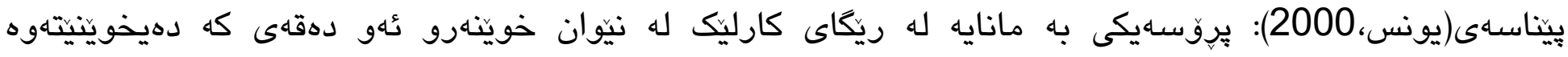

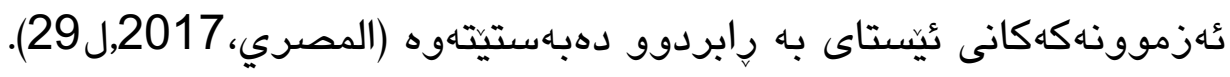

$$
\text { بيناسـى:(نعيمـ 2001) }
$$

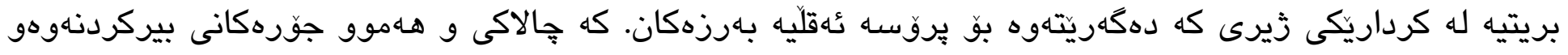

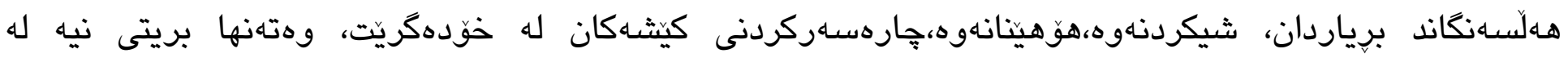

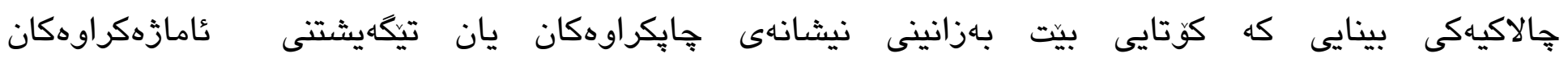
(نعيمة, 2001، 132) (132).

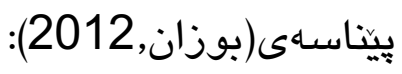
مهبهست له تواناى ميثشكه لهو كاتهى كه زانياريهكان وهردهكريت و كويدهاتهوه, دواتر كريّى دهداتهوه به كوى ئهم

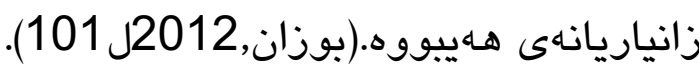

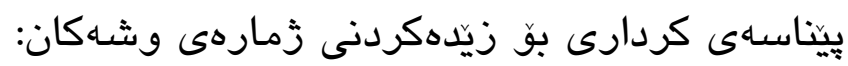

بريتيه له زيادبوونى زمارهى وشهكان للالاى قوتابى خويندكاركه له ريكّاى راهينانهوه فيّرى خويندنهوهى خيّرا

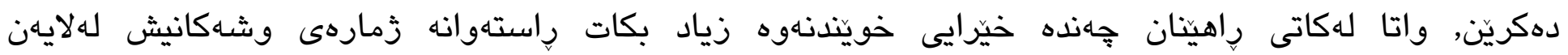
فيَرخوازانهوه زياد دهكات

بينّاسهى كرداريى بو خويندنهوهى خيّرا :

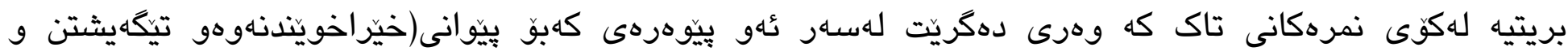

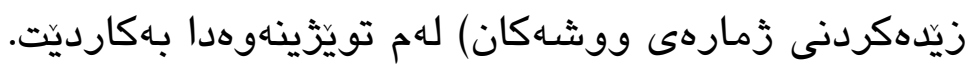




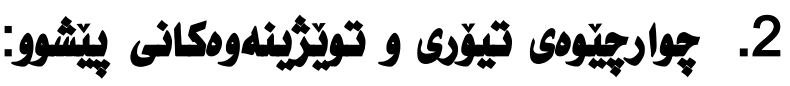

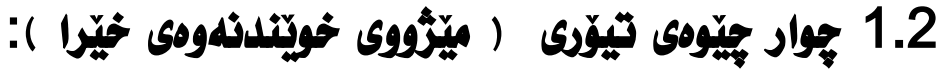

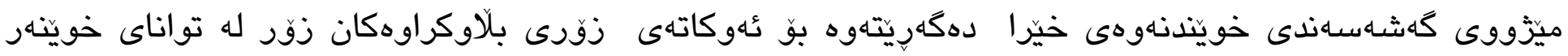

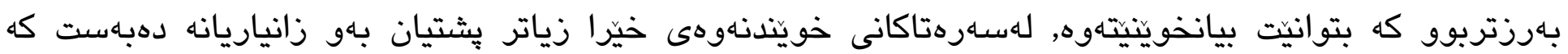

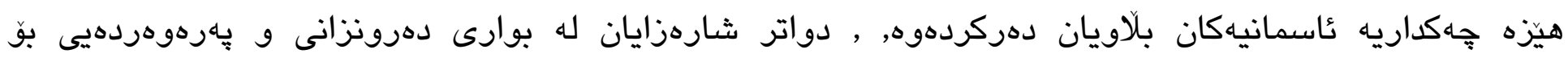

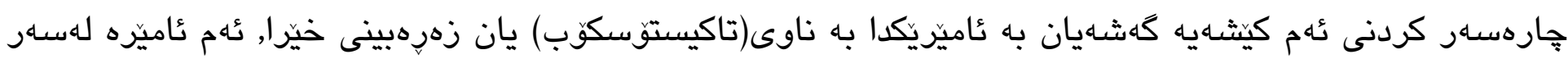

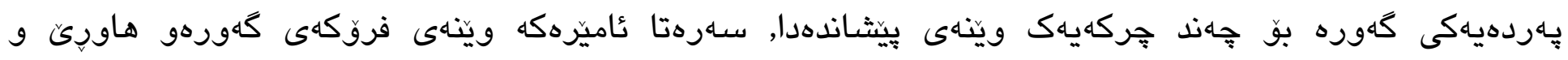

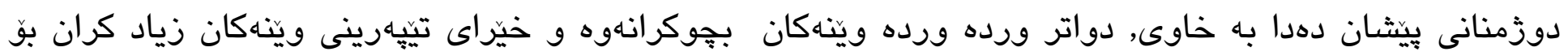

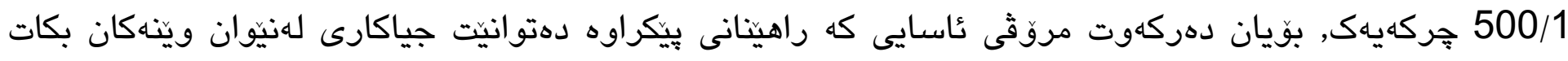

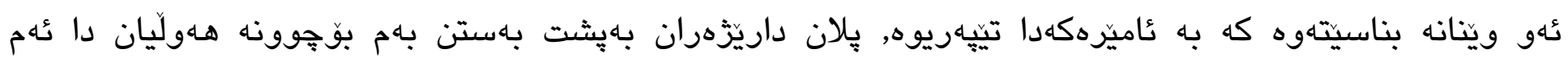

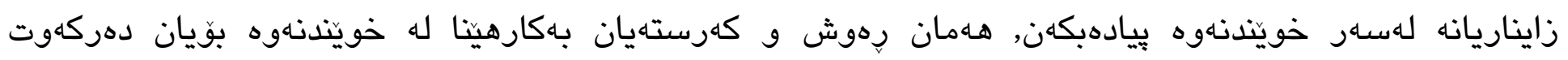

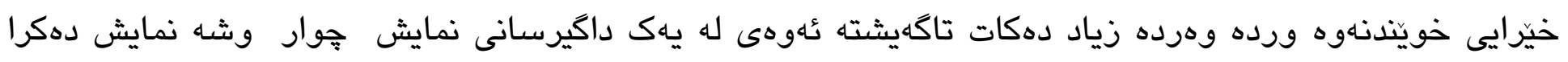

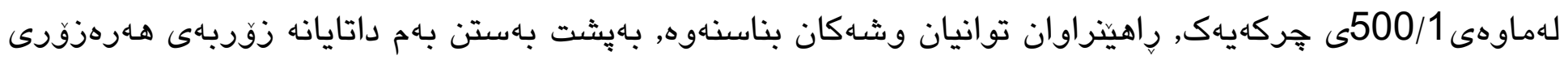

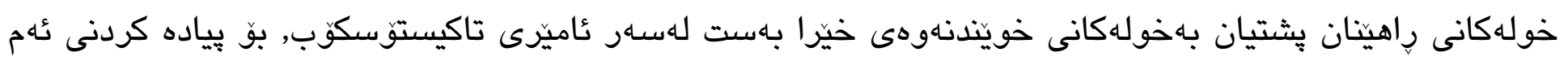

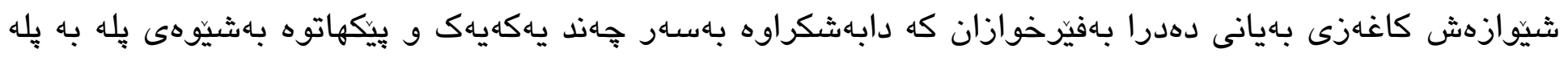

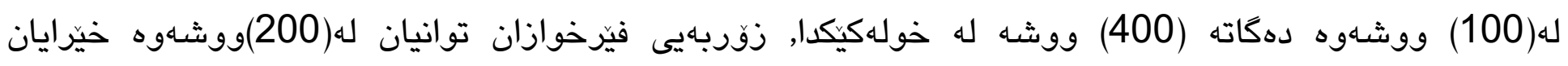

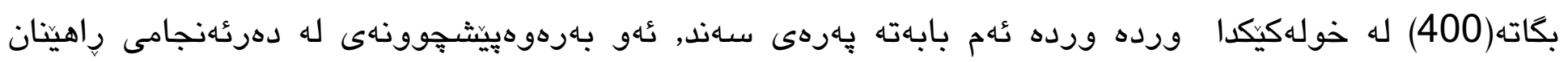

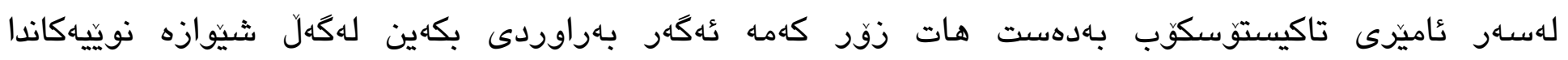

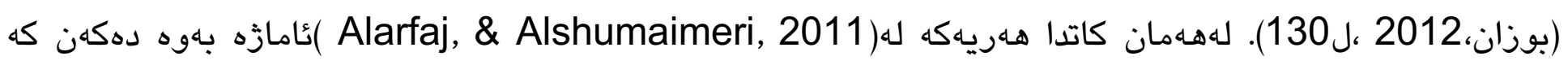

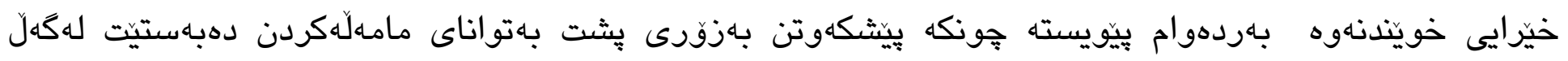

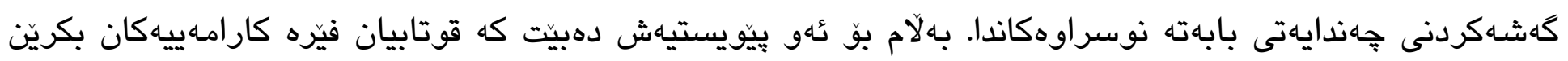

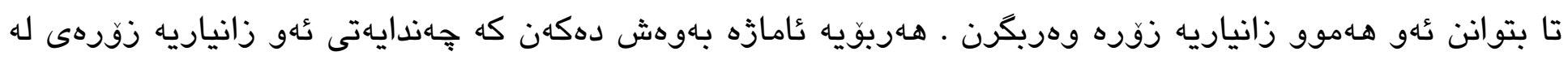

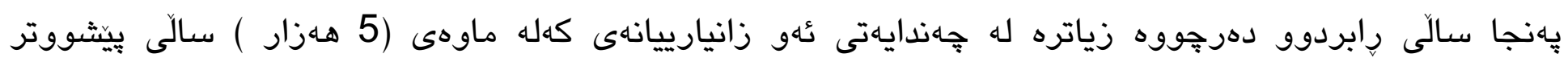

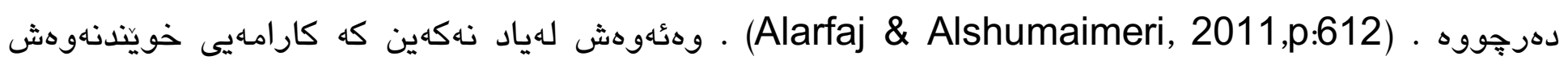

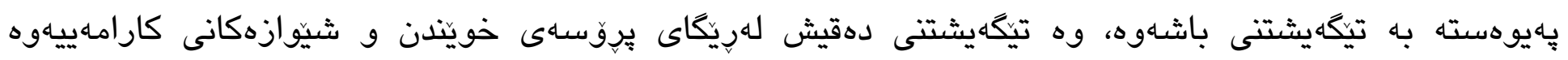

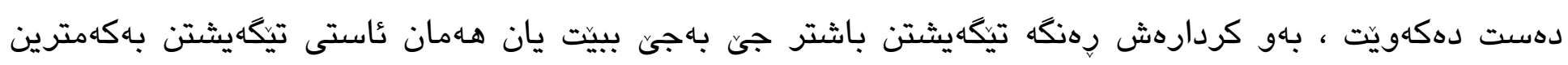

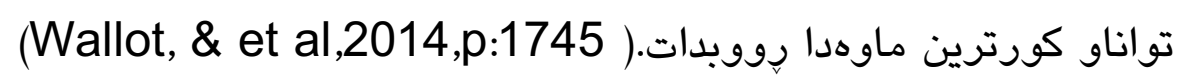




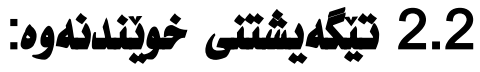

مروق بهرهـامى خويندنهوه و ئهزموونهانيهتى، كه ئهمه كهاشايهتى ديارى دهكات ئاسانكارى دهكات بو

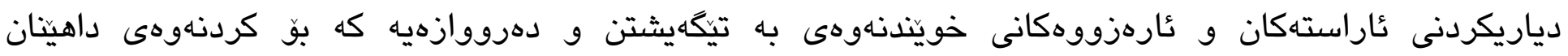

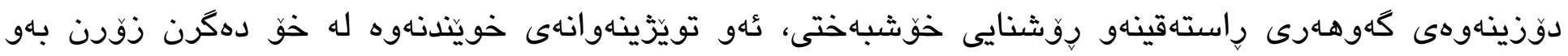

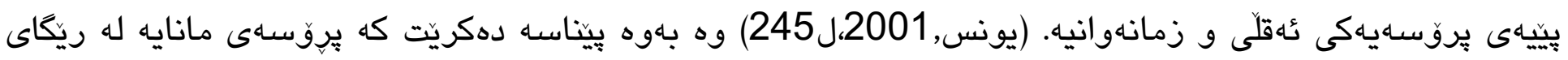

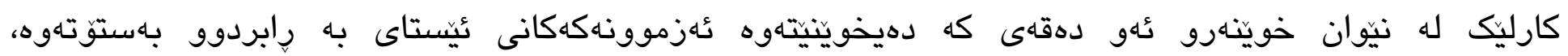

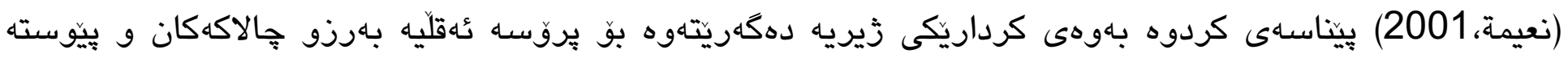

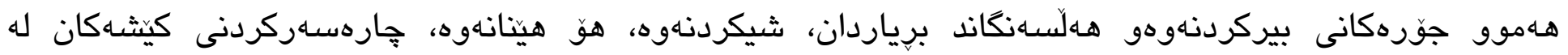

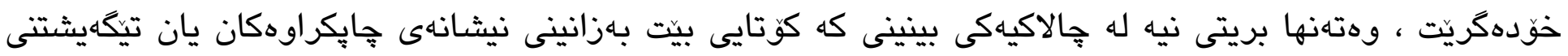

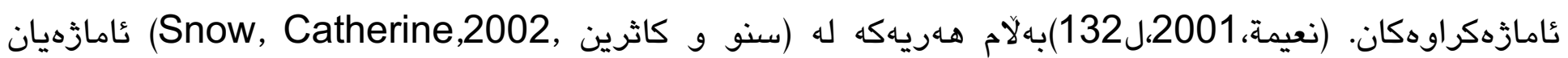

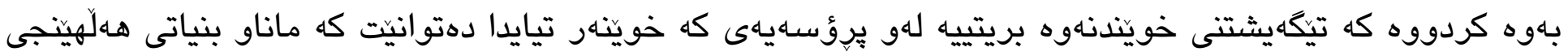

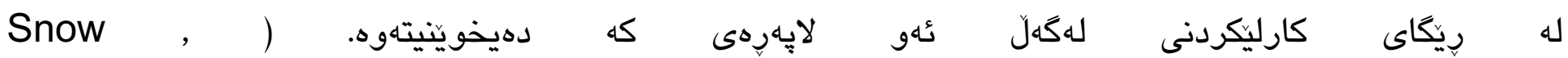

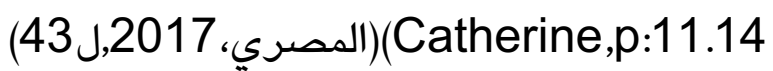

(شينفرد و ميشل،2006) بيّناسهيانكردوه بهوهى وهركيّرانه بو كؤمهليك له نيشانهانى كه بهايوهنديان بهيهكهوه

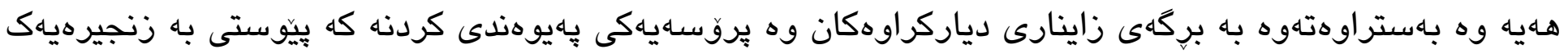

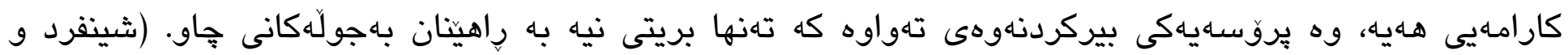

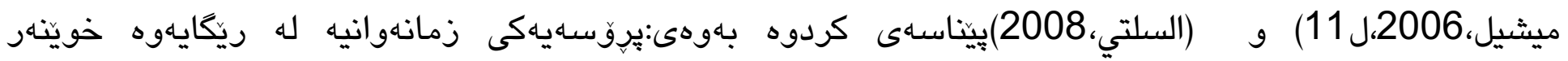

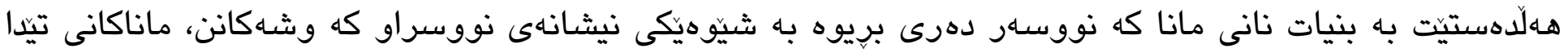

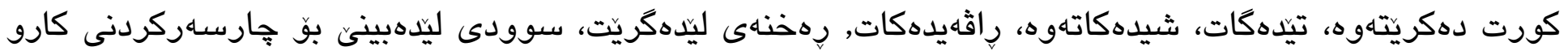
كيثشهانى زيانى(السلتي، 2008، ل2).

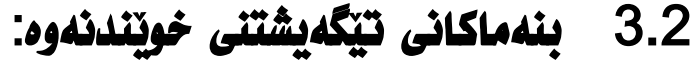

رهجاوى كات دهكات كه خوينّه بيّوستى دهبيّت بو خوينّنهوهى دهفريكى ديارى كراو ئاستى تيكَهيشتى خوينّهر له

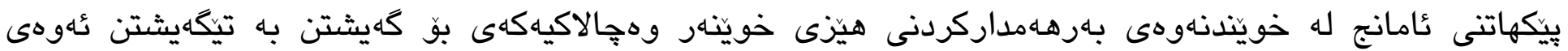

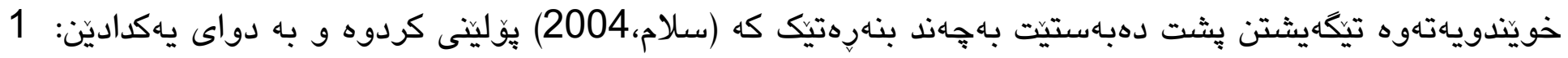

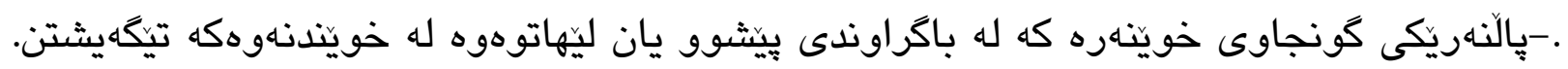

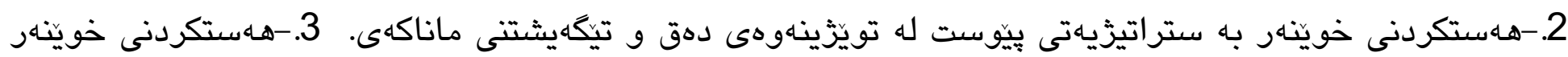

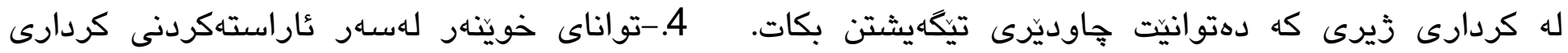




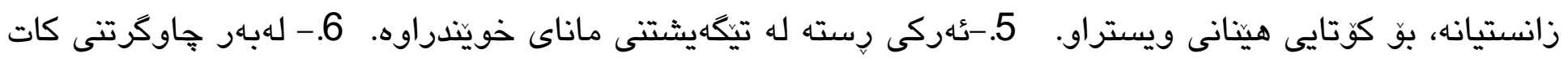

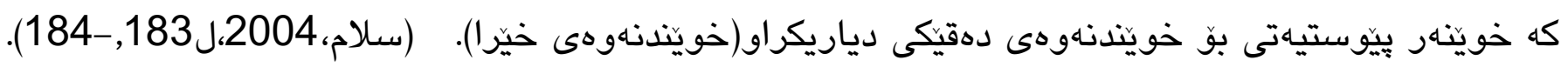

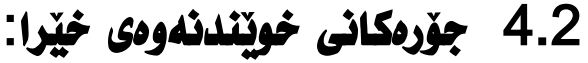

خوينّنهوهى خيّرا بو جهند جوّريك دابهش دهبيت.

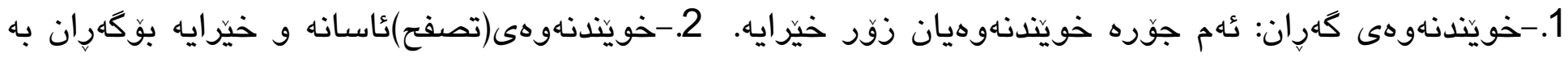

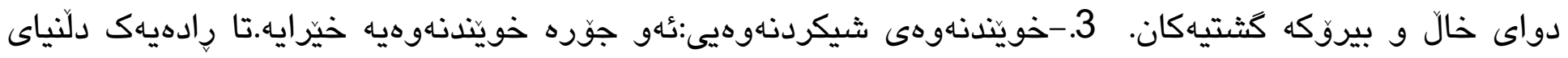

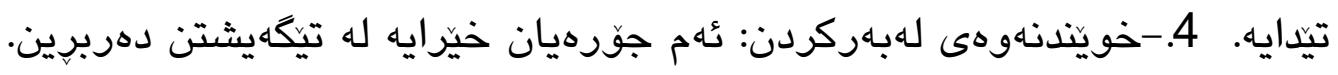

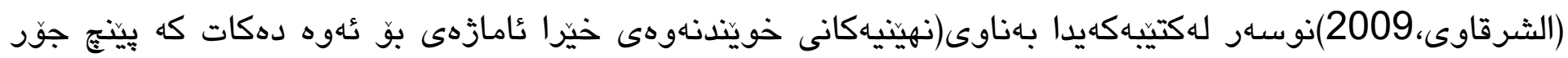

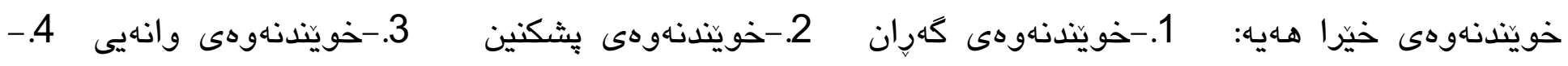

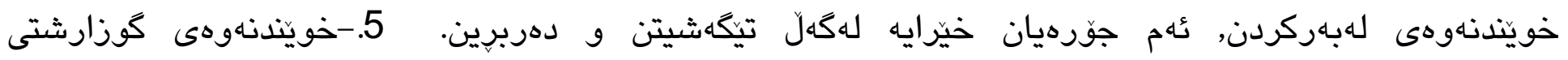

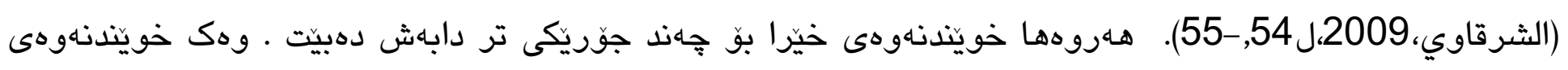

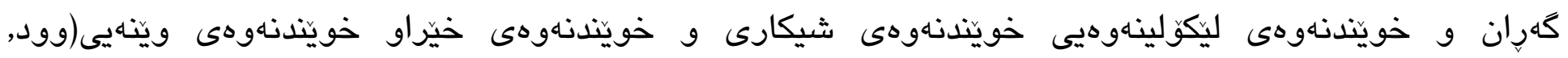
(56-,55، 2009

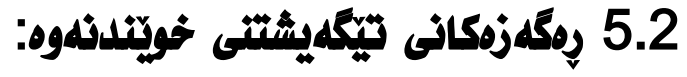

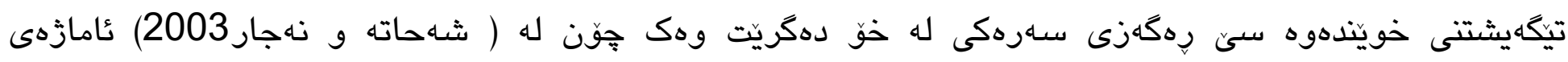

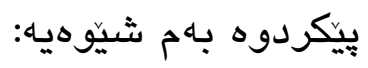

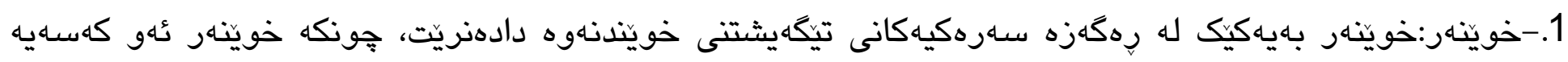

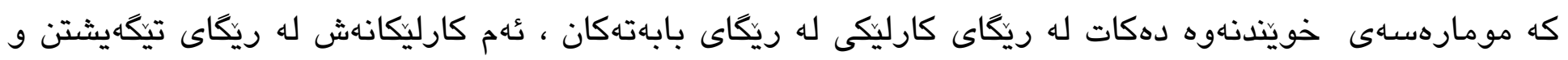

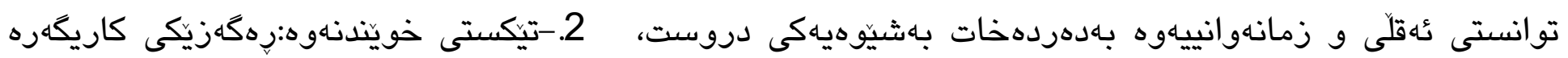

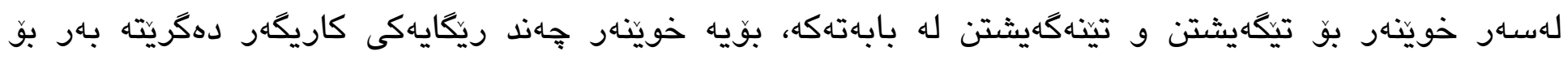

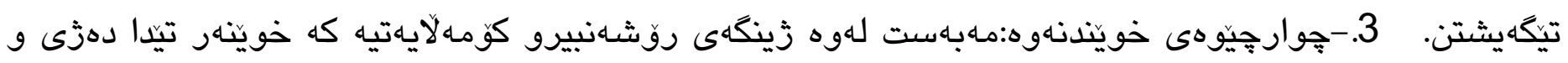

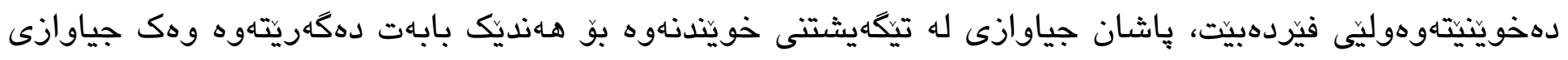

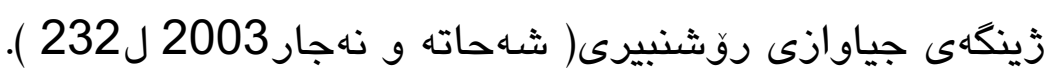

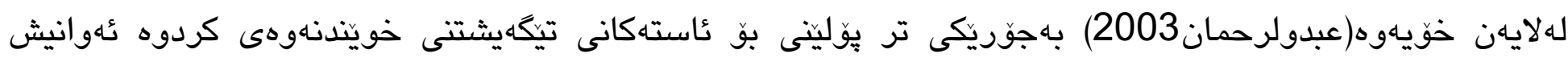

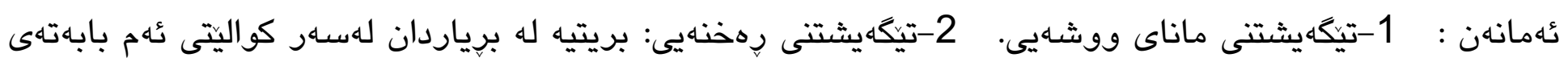




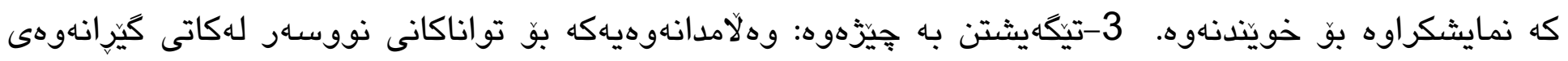

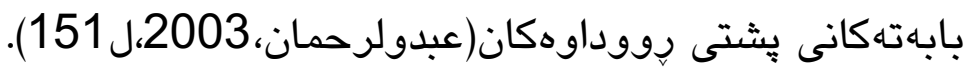

\section{2 تويَّرينهومكانى بِيَّور:}

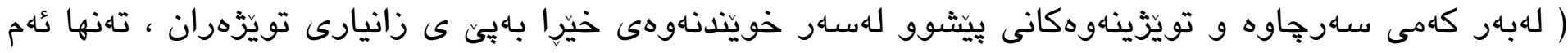

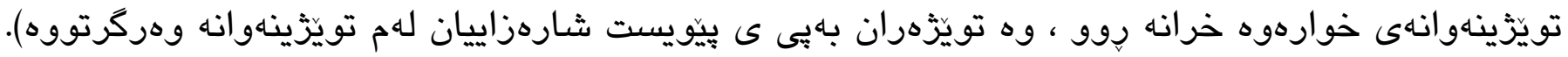

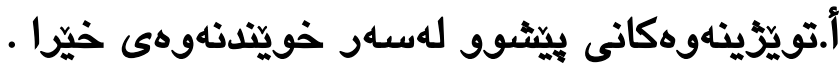

تويّزينهوهى (ئهبو عكر،2014) :

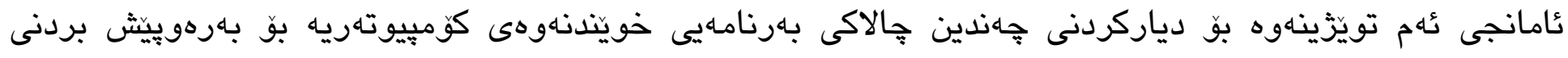

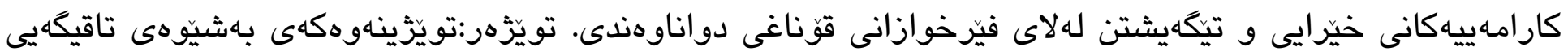

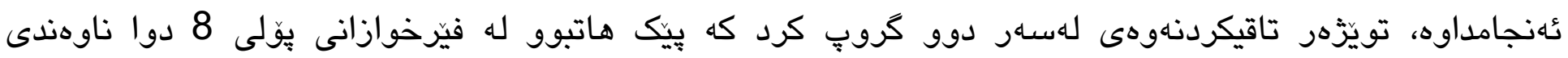

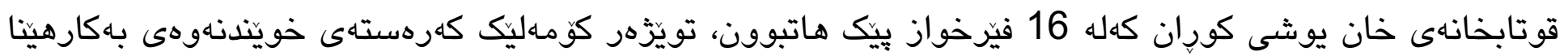

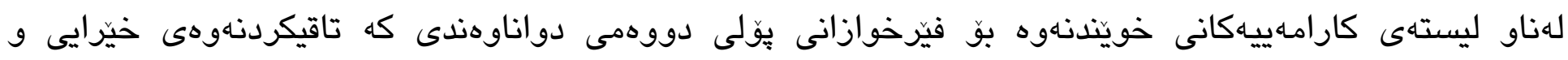

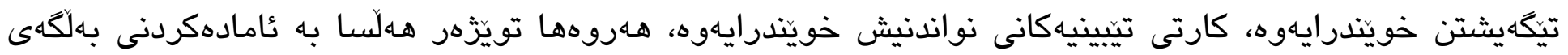

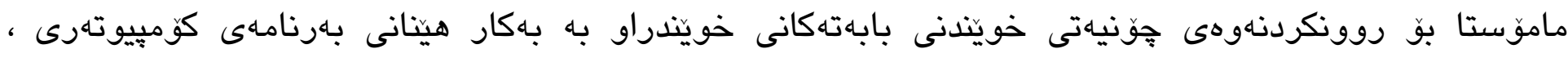

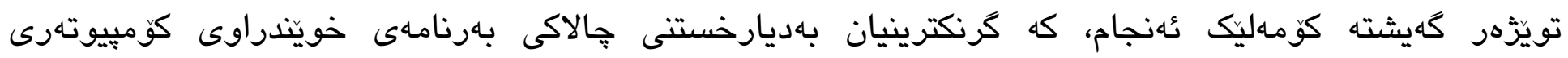

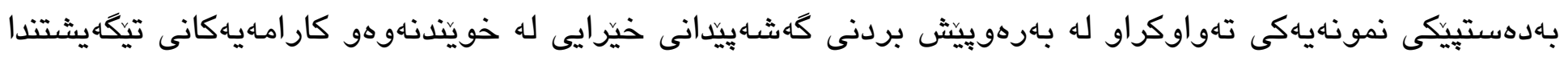

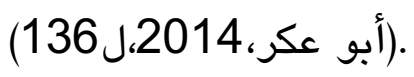

\section{تويّزينهوهى (عبدالحميد،2015):}

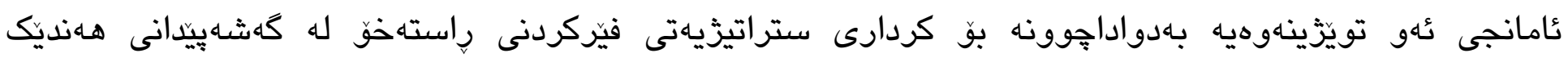

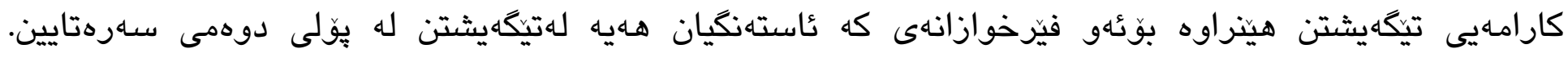

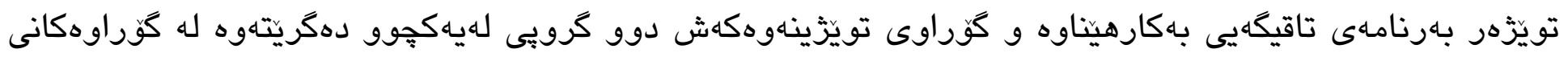

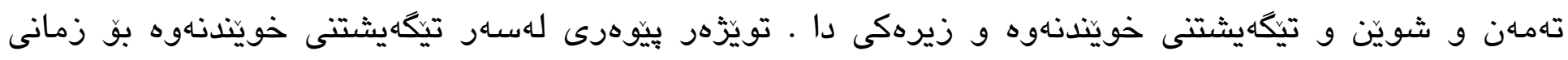

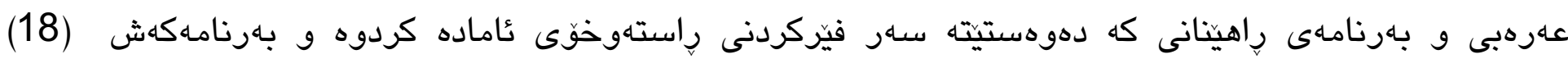


دانيشتن له خو دهكريتّ و دابهش كرا بو دوو دانيشتن لهههر هـهتهيهكدا، ئهنجامهكانى تويَّينهوهى تاقيكهييهكه

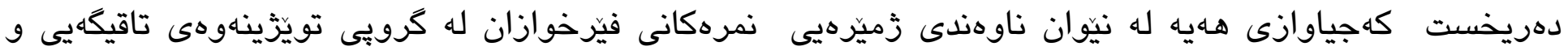

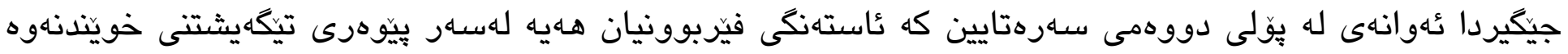

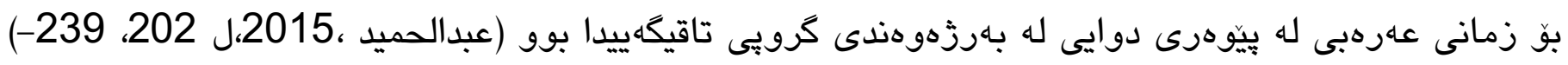

\section{ب.تويّزينهوهكانى بيثشوو كه باسيان له تيكهيشتن كردوه:}

\section{تويَزينهوهى( كاثرين،1989, Cathren):}

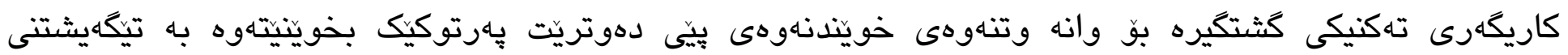

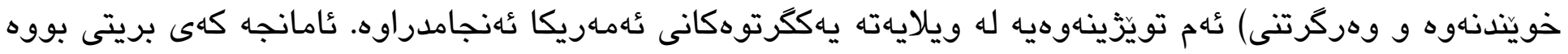

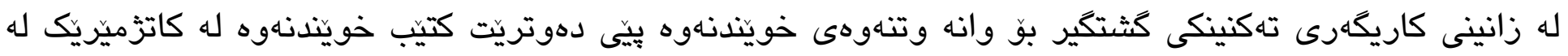

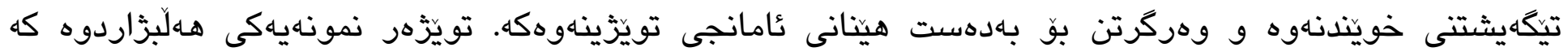

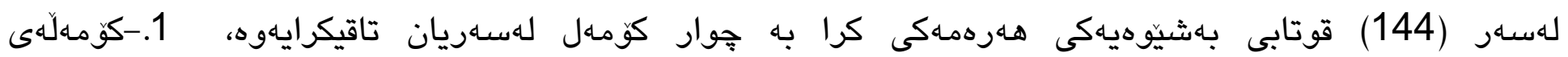

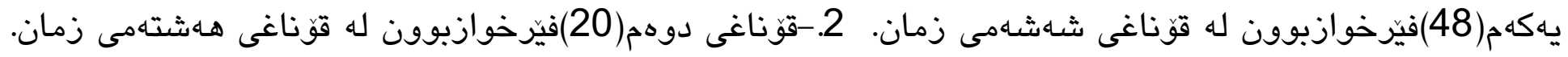

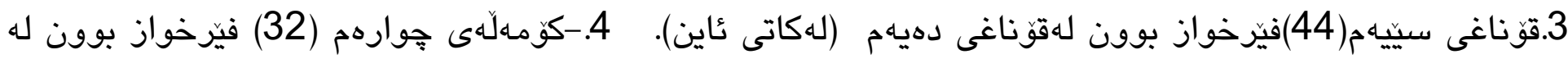

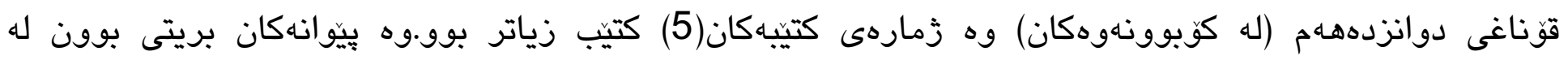

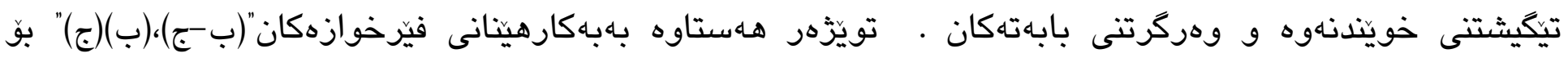

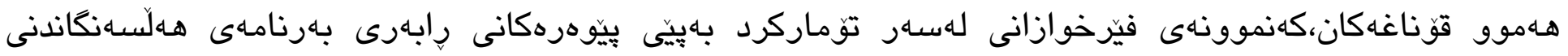

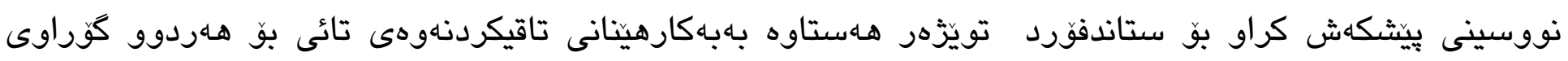

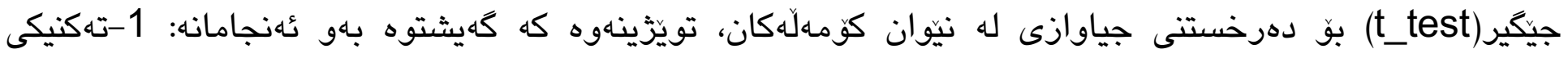

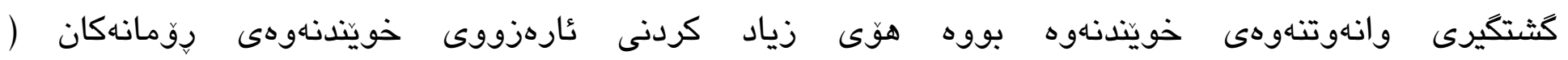

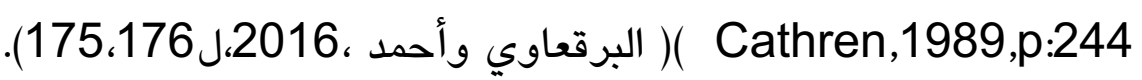

\section{تويّزينهوهى الشديفات والنادى(2017):}

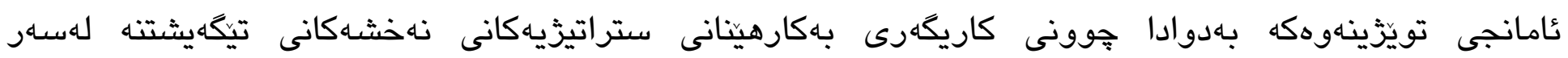

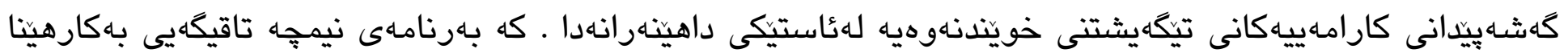

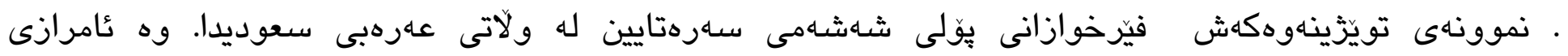

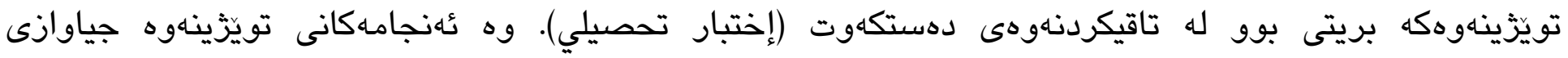

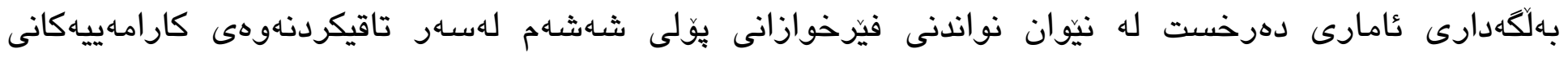

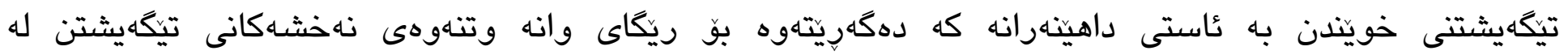




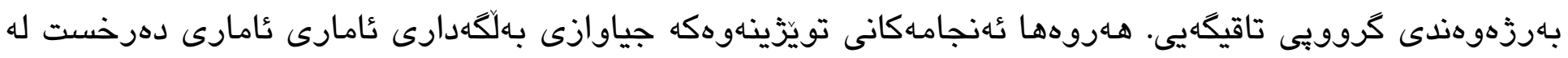

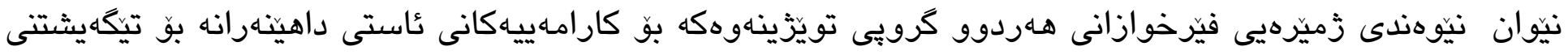

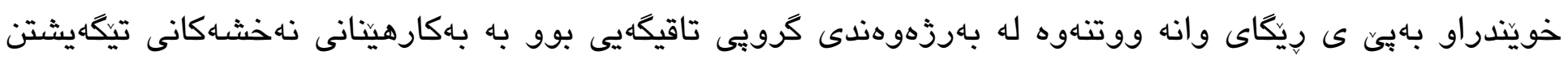

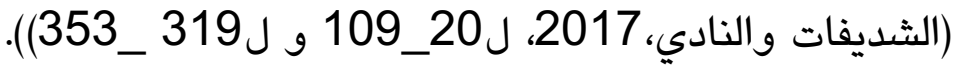

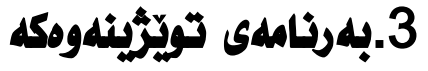

\section{3 ريّبازى تويَّرينهوه:}

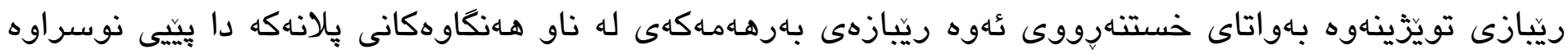

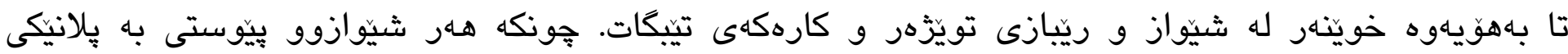

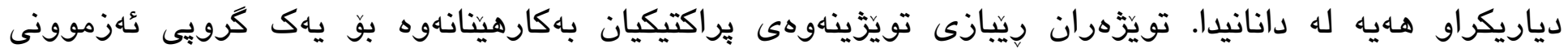

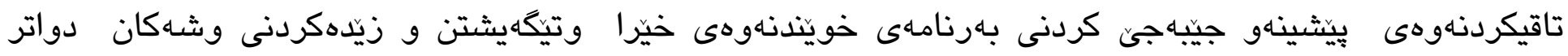

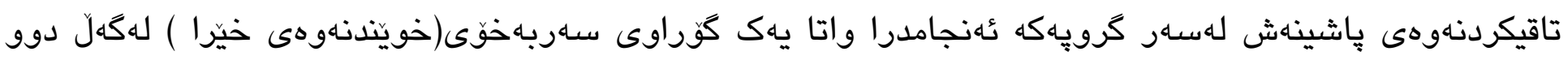

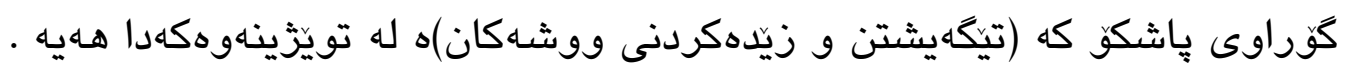

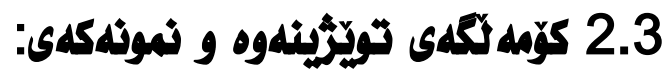

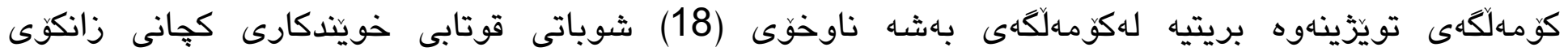

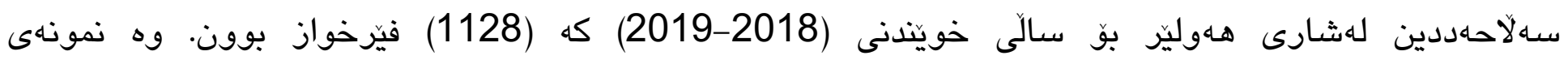

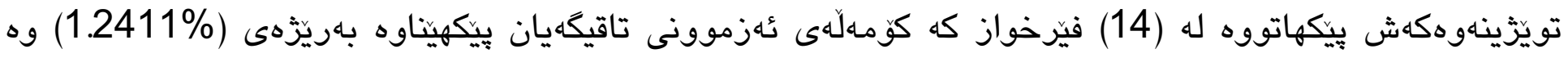

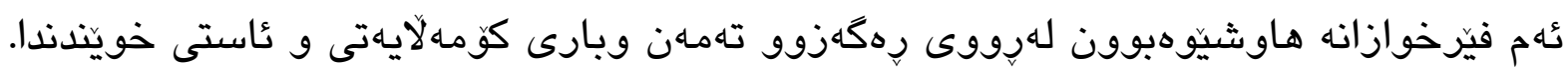

\section{3}

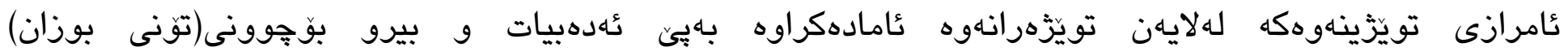

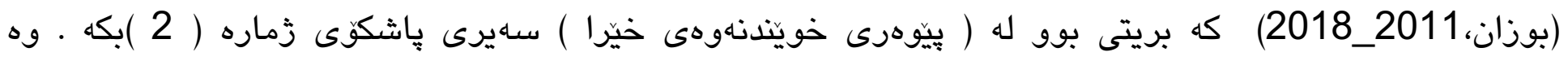

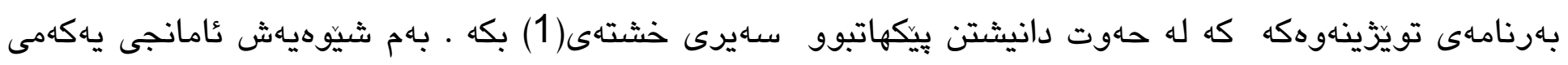

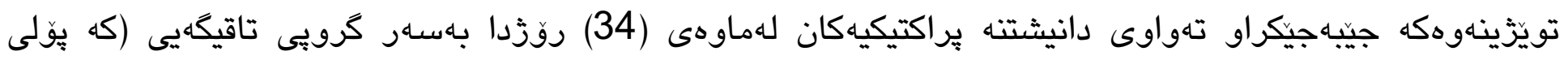

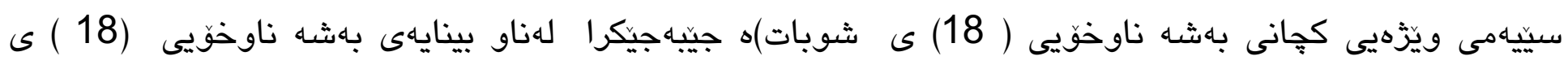

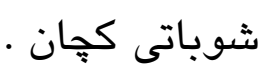


خشتهى زٔماره(1) زماره و بهروار و كات و ناونيشانى دانيشتنهان بيشاندهدات

\begin{tabular}{|c|c|c|c|c|}
\hline ناونيشانى دانيشتنهكان & 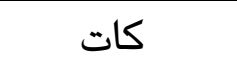 & زمارهى دانيشتن & بهروار & ل رِّذ \\
\hline 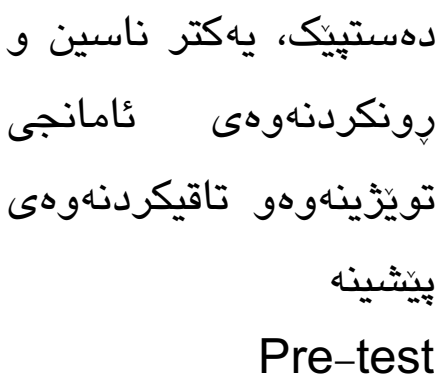 & يهـ كاتزميّر & دانستيشتيكى يهكهم & 29.01.2019 & سيخشاهممه \\
\hline 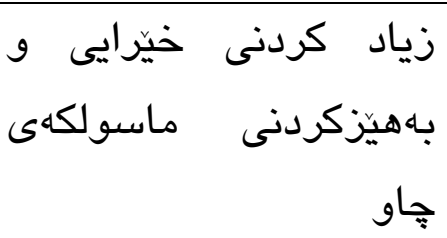 & يهاك كاتزميّر & دانيشتى دووهم & 30.01 .2019 & جوار شـهمـه \\
\hline 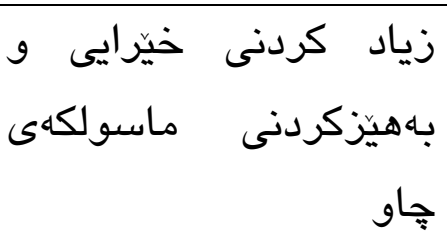 & يهك كاتزَميّر & دانيشتنى سينياهم & 05.02 .2019 & سيخشاهممه \\
\hline 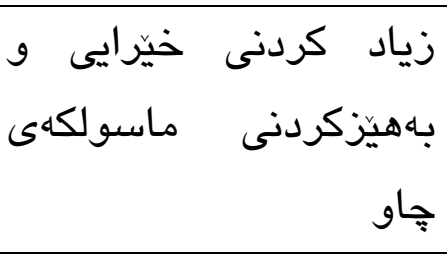 & ياهك كاتزَميّر & دانيشتنى & 12.02 .2019 & سيخشاهممه \\
\hline 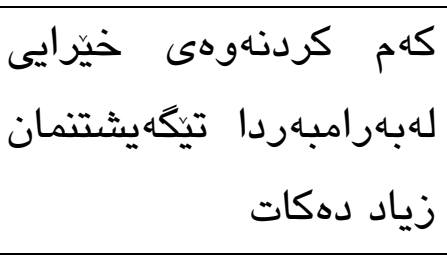 & يهك كاتزميَر & دانيشتنى يِينجهام & 19.02 .2019 & سيخشاهممه \\
\hline 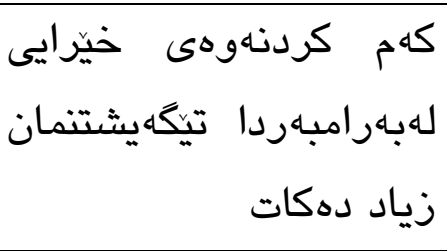 & يهـ كاتزميَر & دانيشتنى & 26.02 .2019 & سيخشاهممه \\
\hline 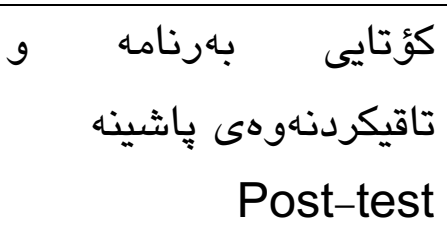 & يها يك كاتزميّر & دانيشتنى & 03.03 .2019 & يهك شهممـه \\
\hline
\end{tabular}




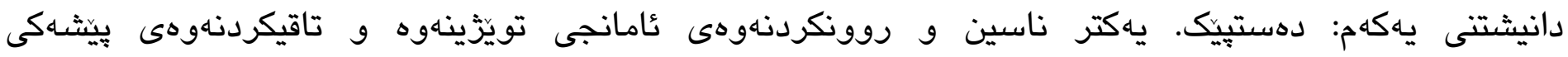

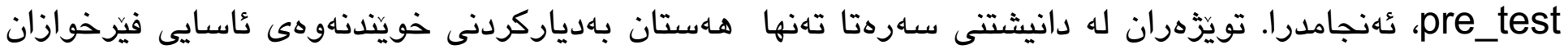

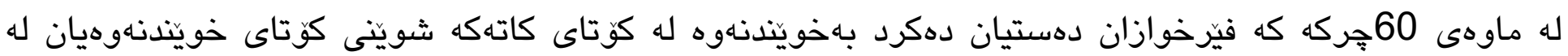
60 جركه ديارى دهكرد دواتر زمارهى عُهم ووشانه ديارى دهكرا كه هـهرفيرخوازيّك لهم ماوهيه خوينتدويهتهوه ناودهبرا بهخيّرايى سـرهتايى.

دانيشتنى دووهم: زيادكردنى خيّرايى و بـهينزكردنى ماسولكهى جاو

زياد كردنى خيراى بينين بهييّى كهم كردنهوهى خيرايى كات نُكگهر هاتوو كاتى خويندنهوهت ريك خستو دياريتكرد و دابهشتكرد بهسهر يه كهى كاتى كونجاو لهسهرهتاى دهستكردن بهخويندنهوه. ئهم ريكخستنهكه

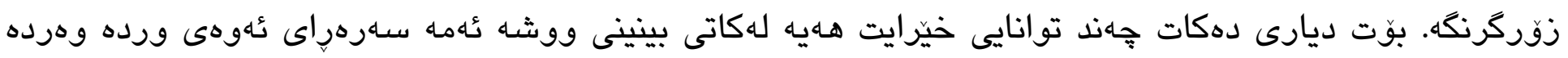
تواناى يادهوهريشت فراوان دهكات(بوزان,2012,136). خويَنهر بههوى نهبوونى كاتيك بو دياريكردن و

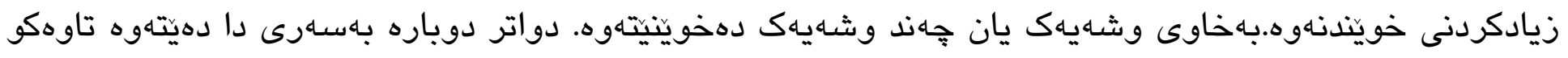

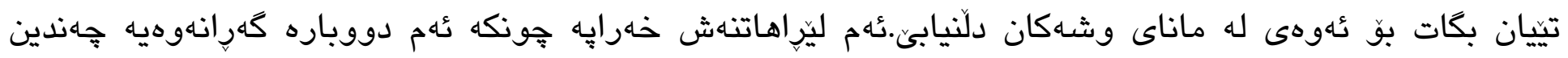

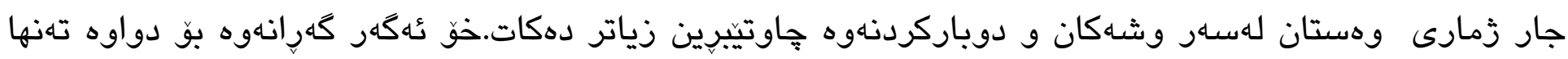

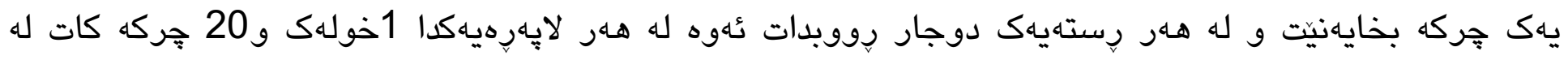

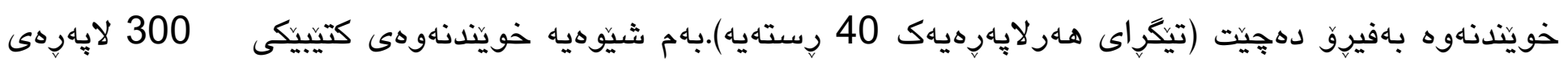
بهنزيكهى ( 5 بوّ 6 ) كاتزميّر دهخايهنيت.خوينتهرى خيّرا نهك له بازدان بوّدواوه لادهدات بـالكو بازدانى

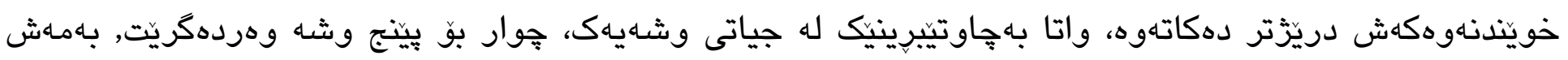

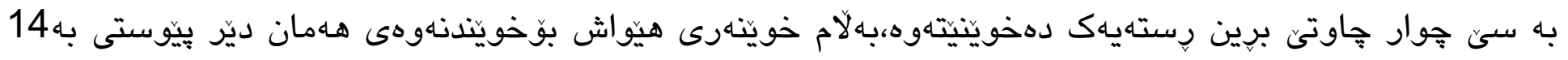

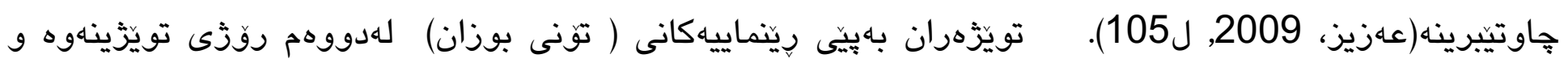

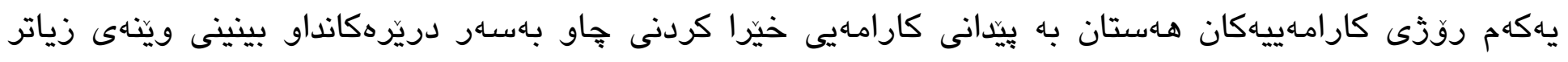

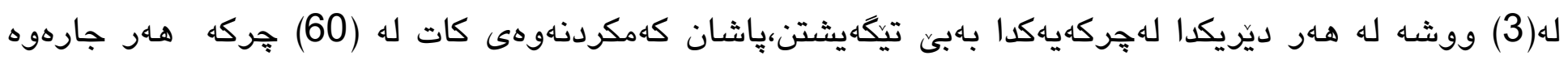

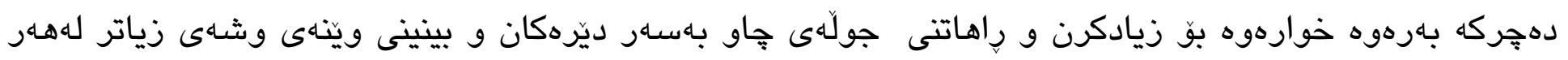

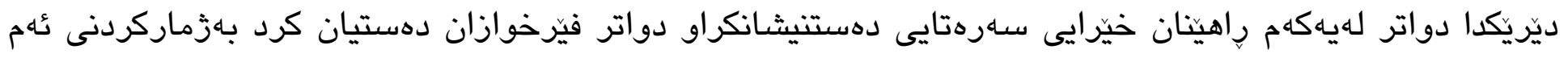
وشانهى له(60) جركهدا خوينديانهتهوه ناوى لينترا خوينّناهوهى يِيشينه، دواتر به زياد كردنى خيّرايى كهمكردنهوهى

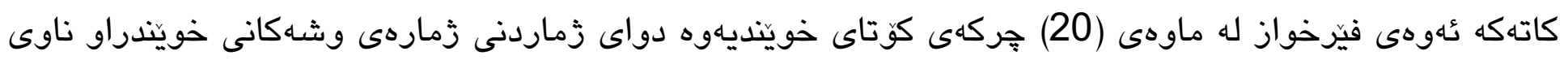
لينزرا خويندنهوهى يֶاشينه . 


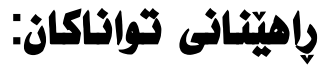

بو بِيوانهكردنى توانايى: 60 جركه بهايِّى دياريكردنى ئهم كاته زمارهى ئهم ووشانه ديارى دهكهين كهلهم ماوهيهدا

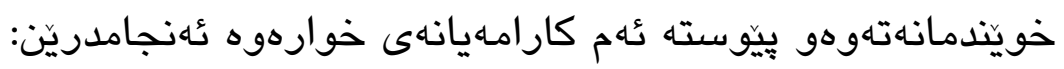

1.فيزرخواز ماوهى يهك خولهك دهست دهكات بهخويندنهوه، دواتر بيّوسته خالّى دهستيّيك و كوتاى دهست نيشان

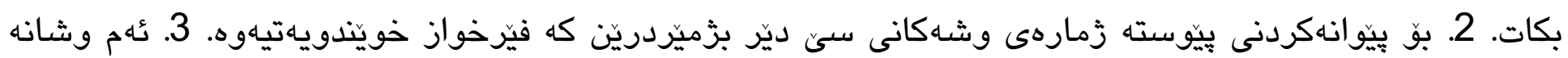

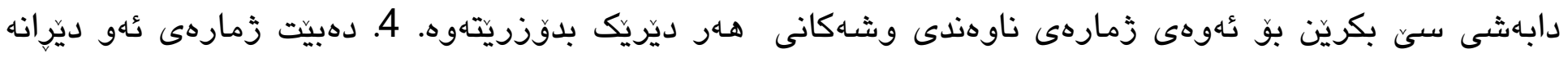

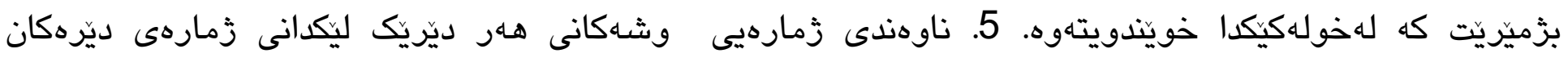

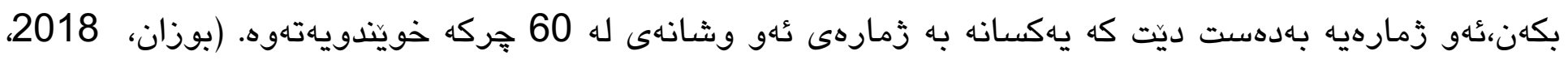

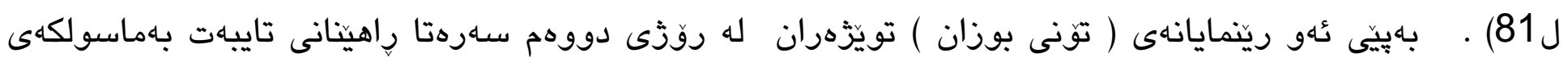

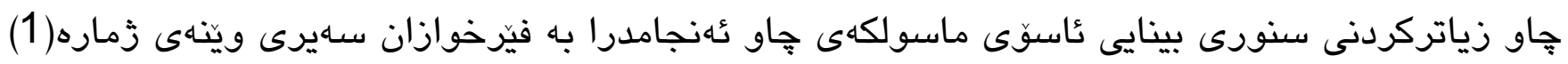

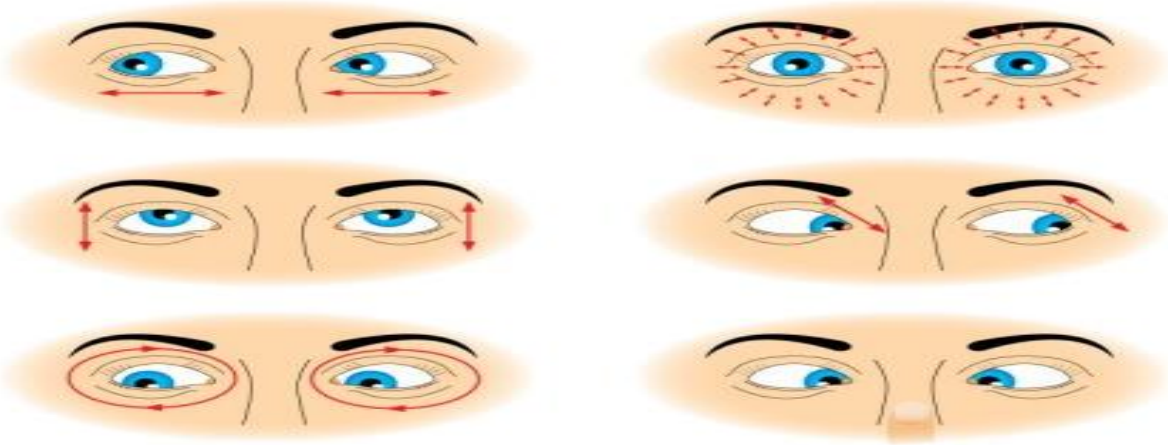

دانيشتى سيّياهم:زياد كردنى خيّرايى خويندنهوه بههيزّكرجنى ماسولكهى جاو.

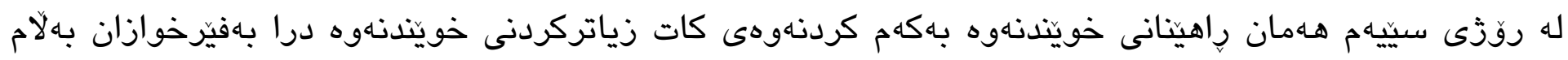

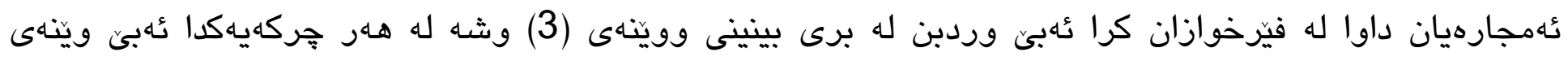

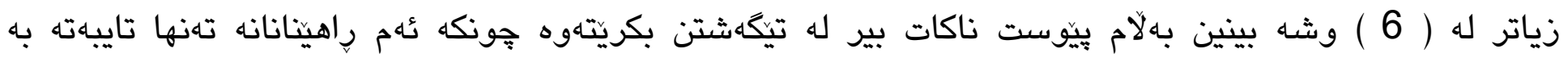

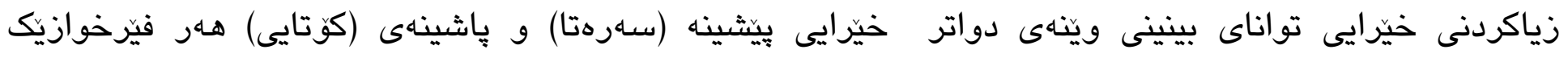

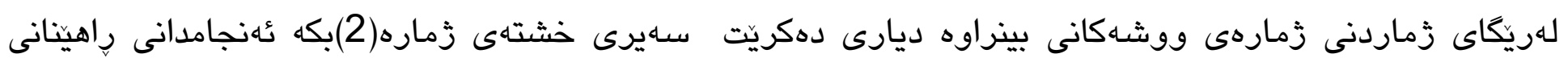
هاهتانهى يهكيك لهبهشداربوانى تويَّزينهوهكهيه. 
خشتهى زُماره(2) تُهركى هـفتانهى ماللهوهى يهكيك له فيّرخوازانه لهماوهى تويّزّينهوهك ئهنجاميداوه

\begin{tabular}{|c|c|c|c|c|}
\hline تيكَاهيشتن & كردو & خيّرايى كوَتايى & سيَرايى & زَمارهى \\
\hline & 30 ووشـه & 1650 & 1620 & 1 \\
\hline & 40 ووشـه & 1820 & 1780 & 2 \\
\hline & 44 ووشـه & 1850 & 1806 & 3 \\
\hline & 61 ووشـه & 1951 & 1890 & 4 \\
\hline & 65 ووشـه & 1995 & 1930 & 5 \\
\hline & 94 ووشـه & 2306 & 2400 & 6 \\
\hline & 97 ووشـه & 2700 & 2603 & 7 \\
\hline & 106ووشه & 2966 & 2860 & 8 \\
\hline & 140ووشـه & 3090 & 2950 & 9 \\
\hline
\end{tabular}

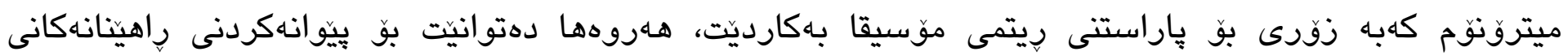

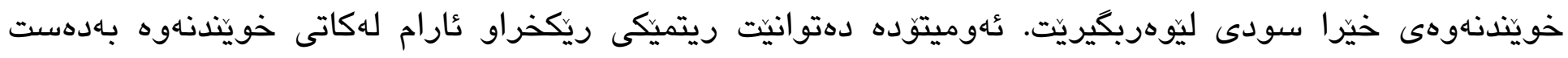

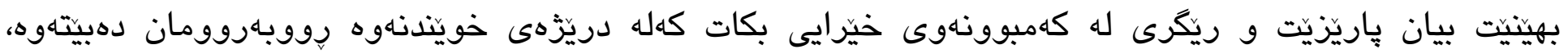
كاتيك باشترين ريتم وهردهكرين دهتوانين خيّرايى خوينّناهوهمان بهزياد كردنى ريتميكى زياده له خولهيكـا

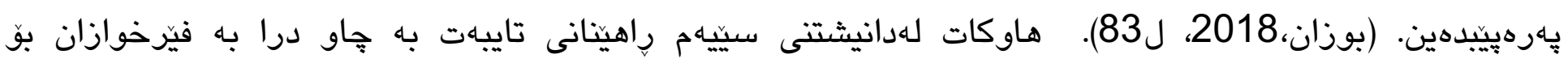

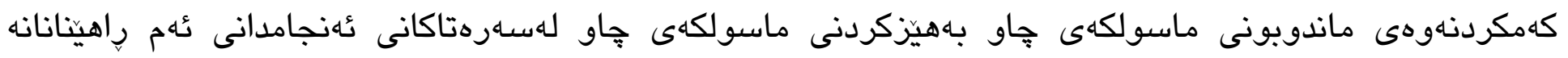

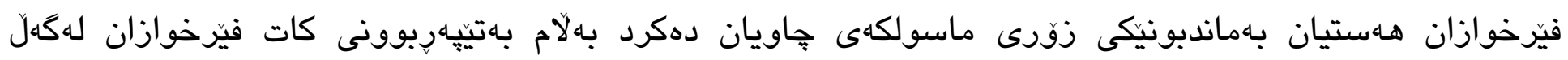
راهينانهكان راهاتن.سهيركه وينتهى زماره (2) تايبهته بهاماسولكهى جاو. 


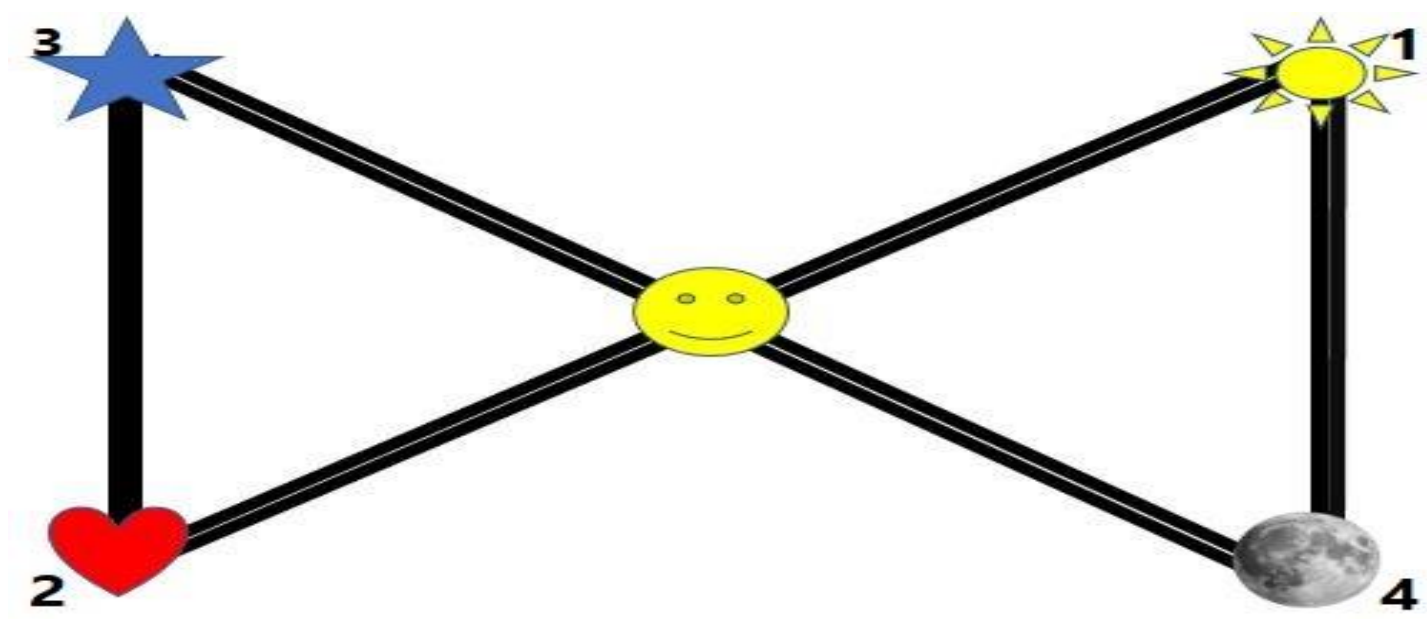

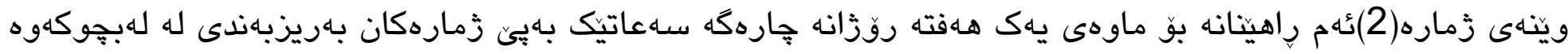

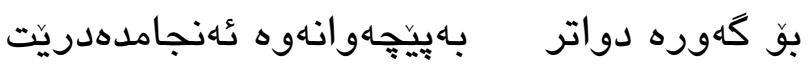

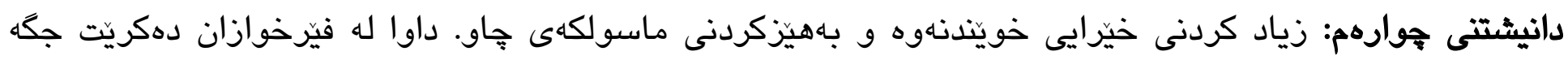

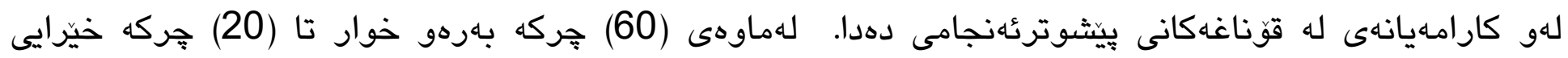

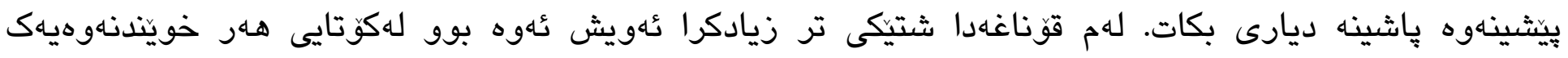

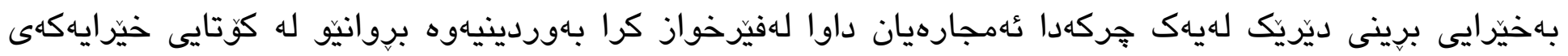

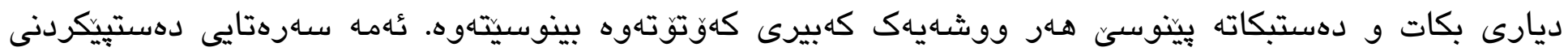

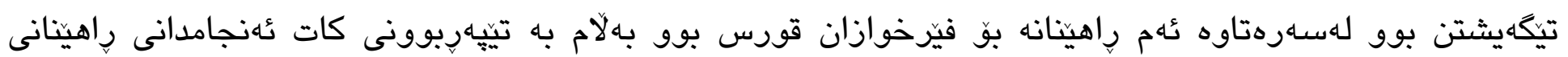

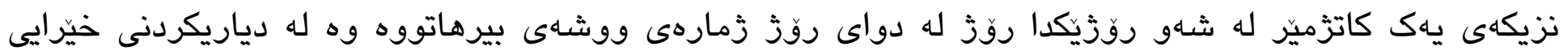

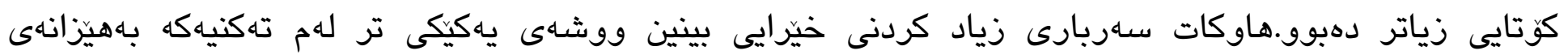

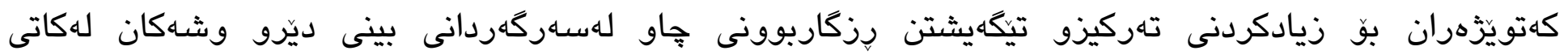

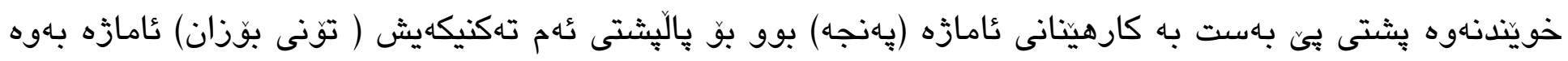

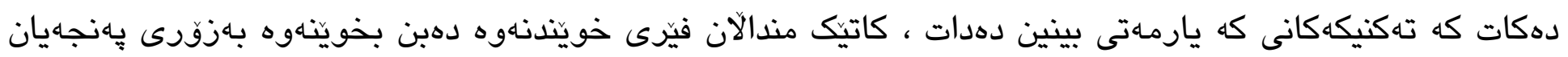

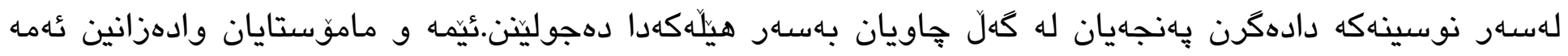

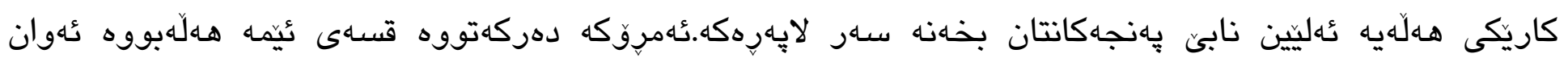

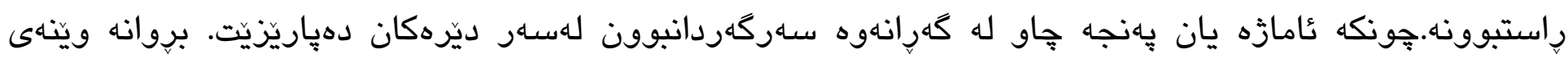

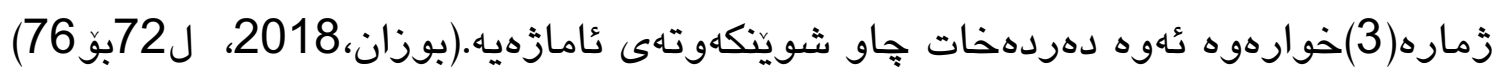



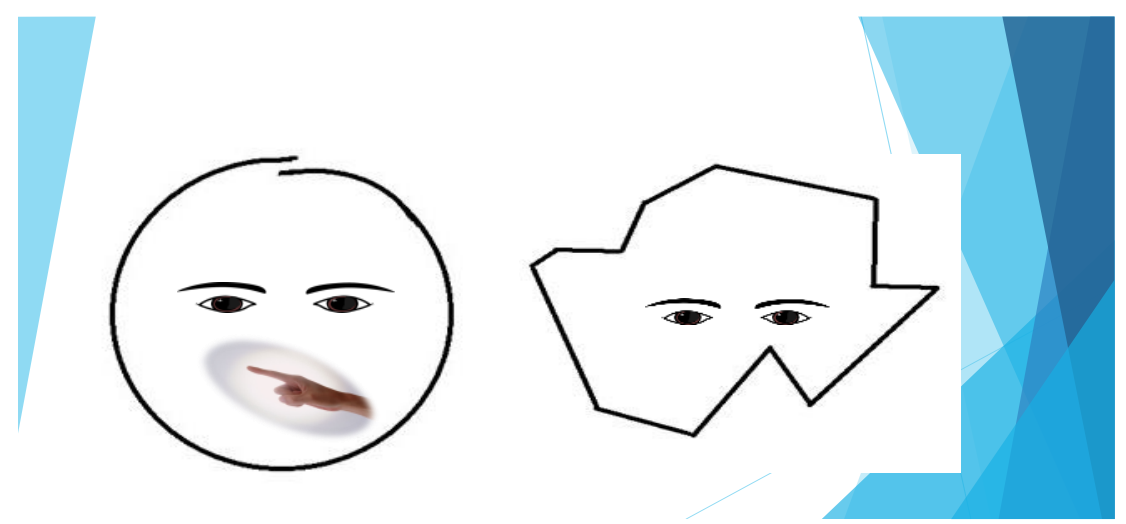

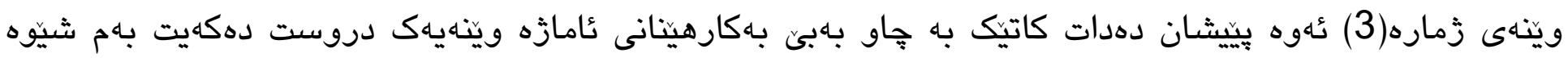

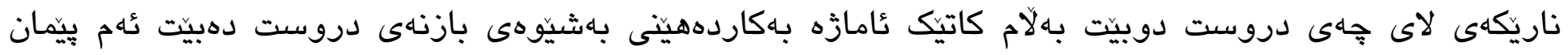

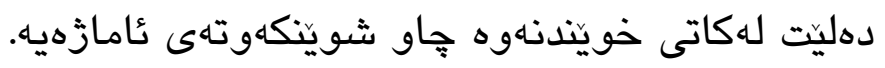

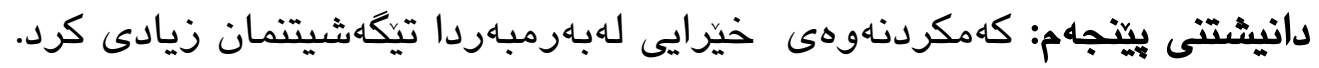

لهسهرهتادا تويّزهران هـهوو تئه باوهره نادروستانهى بوّ فيّرخوازانيان رووونكردهوه كهبووه بهخوو ريَكره لهوهى خيّرايى تهركيزو تيكَهيشتيان زياد بكات . كاراميهكانى خويندنهوى خيّرا تئه باوهره نادروستهكان كه لهمنداليهوه

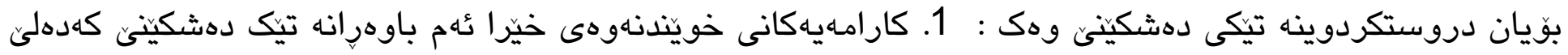

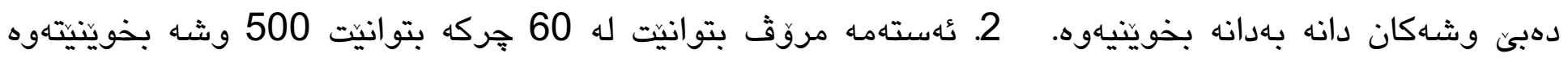

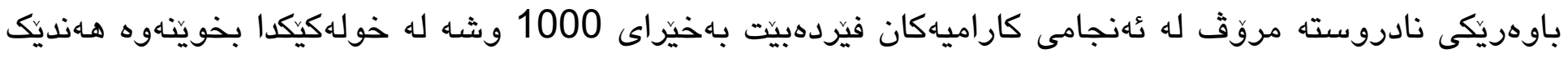

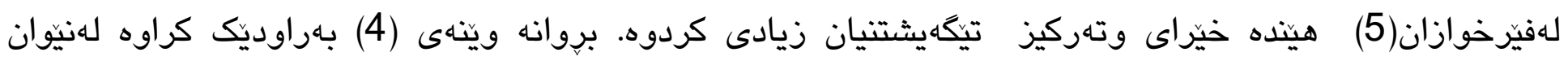

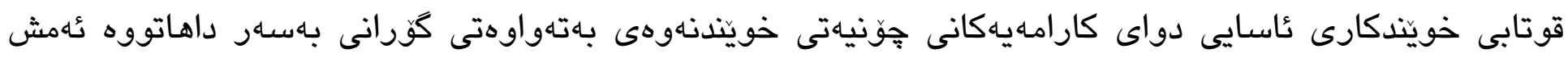

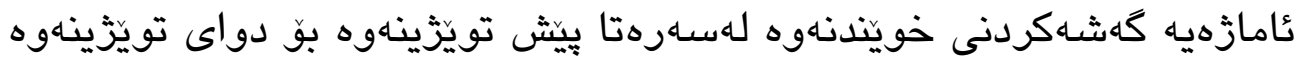

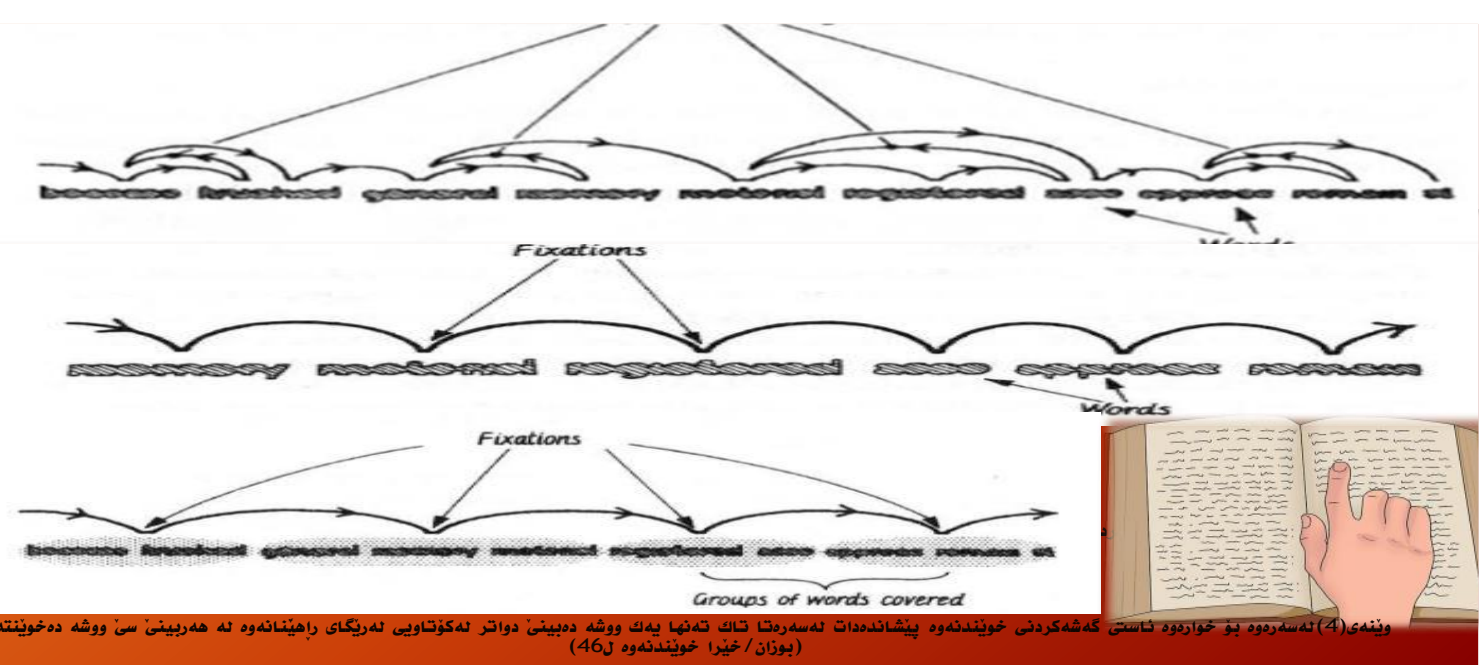




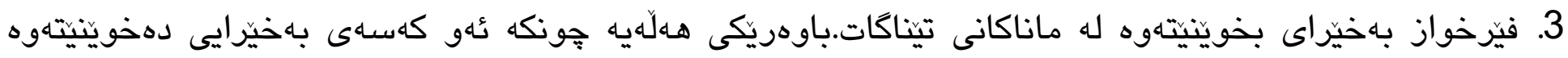

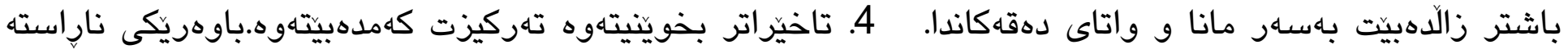

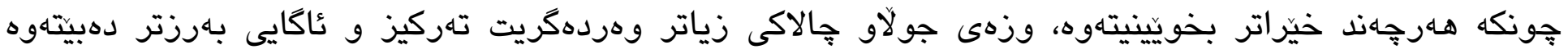
بروانه وينّاهى زماره(5)
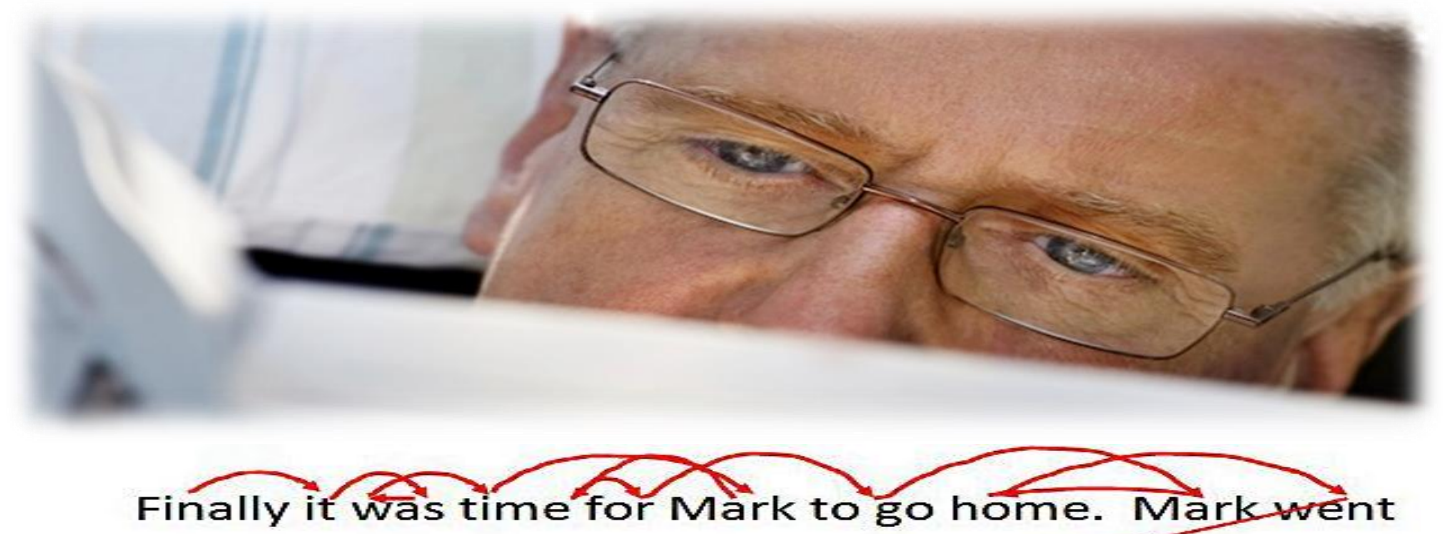
to the tree togethis bike. His bike was gone! Mark called to Jack. They lgoked for the bike besidethe slide. They looked by the swings and bar's. They could not find the bike. Thên Jack started to laugh. He pointed under a

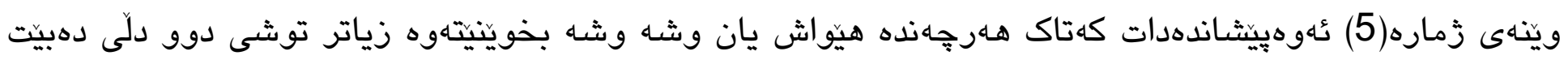

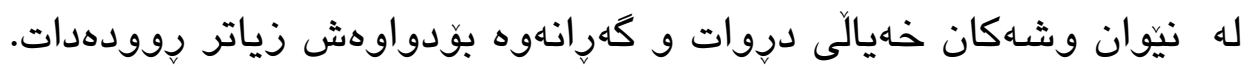

تهكنيكى كارا:

لهديارترين ئهو ميكانزمانهوهى دهكريت سوديكى زوّر له بهكارهينانى بكهين بينّ دهوتريت (تهكنيكى بوزان) كه زاناى

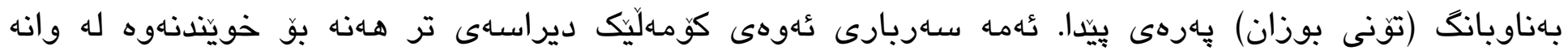

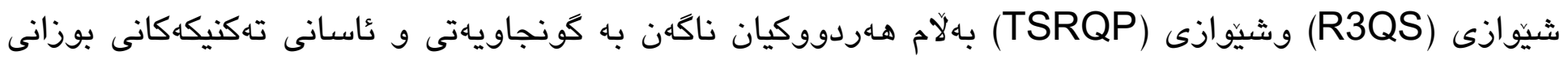

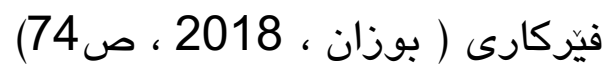

دانيشتى شهاشهم: كهمكردنهوهى خيّرايى لهبهرمبهردا تيكَهيتنمان زيادى كرد

خويندنهوه لهماوهى (60) جركه دواتر دهست بهخيّرايى زياترو كهمكردنهوهى كات بههـمان شيّوهى كارامهيهكانى

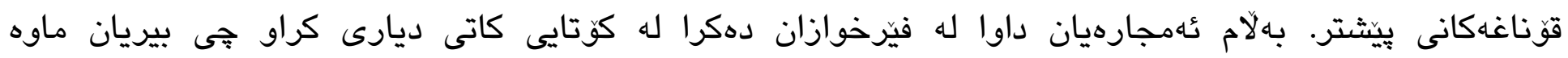

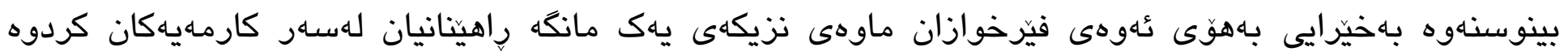

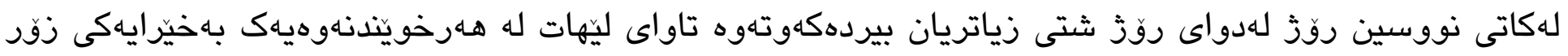




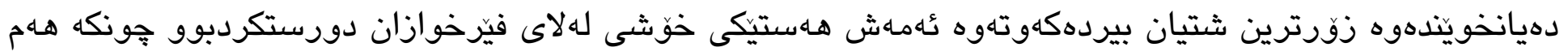

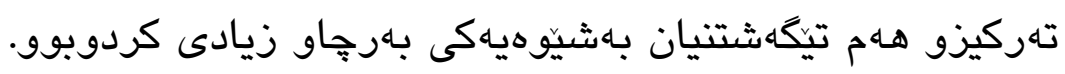

\section{تيكّه يشتنى تيكست :}

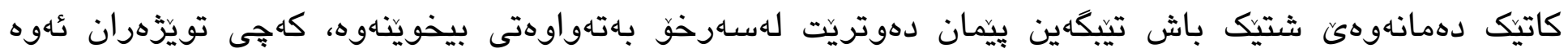

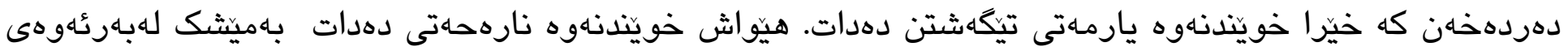

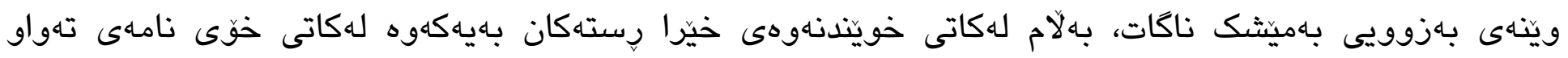

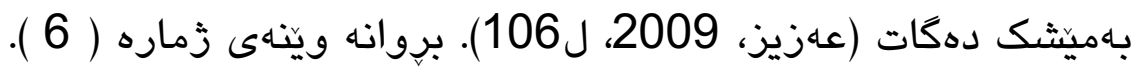

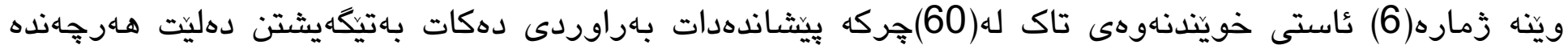

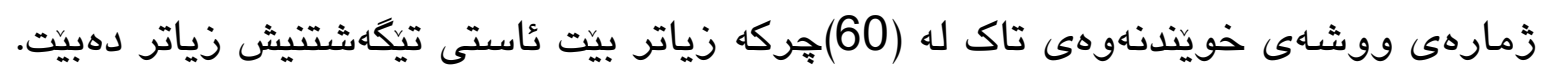

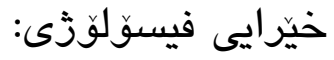

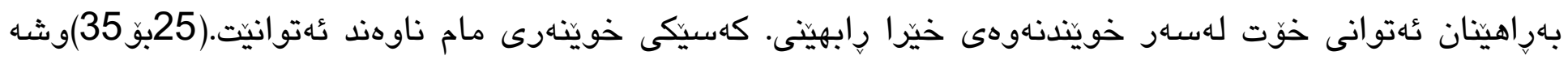

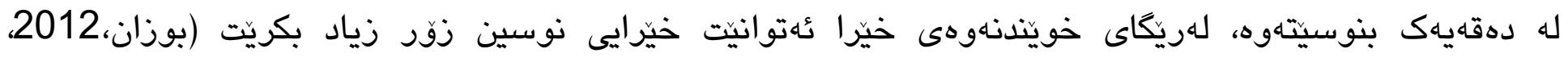

$\begin{array}{llll}\text { Reader } & \text { Speed wpm } & \text { Comprehension } \\ 1 & \text { Poor } & 10-100 & 30-50 \% \\ 2 & \text { Average } & 200-240 & 50-70 \% \\ 3 & \text { Functionally literate } & 400 & 70-80 \% \\ 4 & \text { Top } 1 \text { in } 100 & 800-1000 & 80+\% \\ 5 & \text { Top } 1 \text { in } 1000 & 1000+ & 80+\%\end{array}$

تاقيكردنهوهى ياشينه (Post test) لهسهر فيّرخوازان ئهنجامدرا هـريهك له فيّرخوازن بهريّزهيهكى بهرجهاو خيّرايى

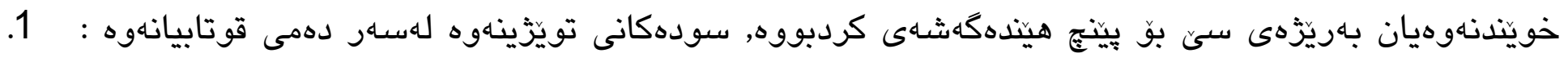

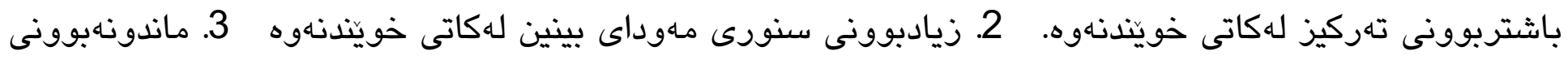

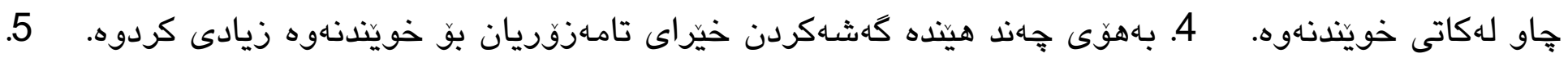

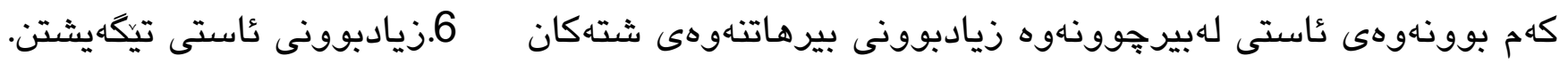




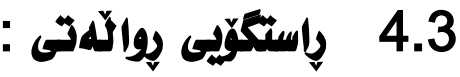

راستكزى ماناى وايه تاقيكردنهوهكه يِيوانهى ئهم شته دهكات كهبوى دانراوه وه تاقيكردنهوهى راستكگّى ئهو

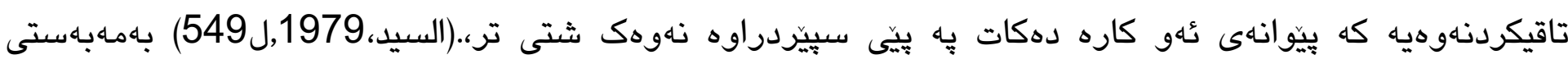

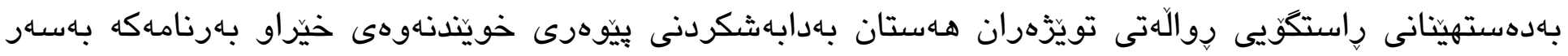

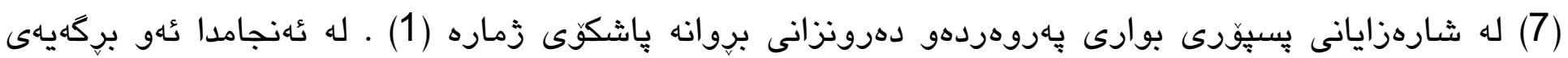

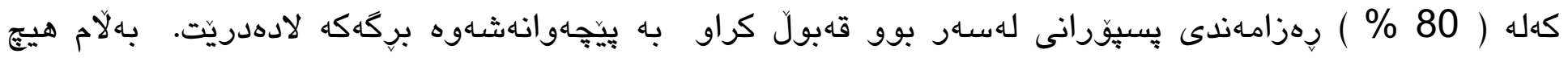

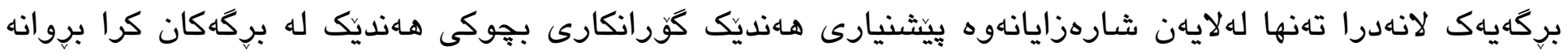

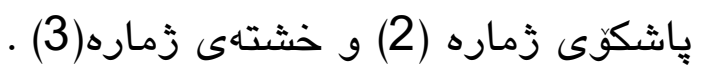

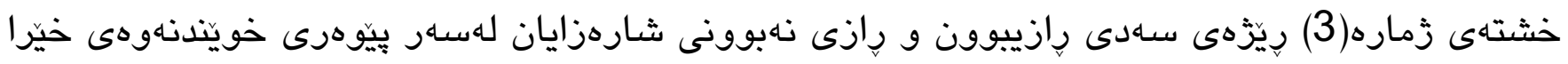

\begin{tabular}{|c|c|c|c|}
\hline \multicolumn{2}{|c|}{ رازى بوون } & \multirow[b]{2}{*}{ بركَهكان } & \multirow[t]{2}{*}{ ي يَيْهرهكان } \\
\hline$\%$ & زماره & & \\
\hline$\% 100$ & 6 & 1.2 .3 .4 .5 & خويندناوهى ئاسايى \\
\hline$\% 100$ & 6 & 6.7،8،9.10،11،12 & خويندناهوهى خيّرا \\
\hline$\% 100$ & 6 & $13 ، 14 ، 15 ، 16 ، 17$ & تيكَّهيشتن \\
\hline$\% 100$ & 6 & تاقيكردناوهى داقى نوسراوى & 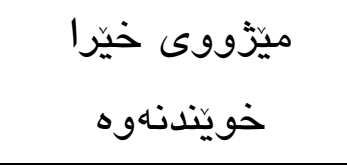 \\
\hline
\end{tabular}

\section{3}

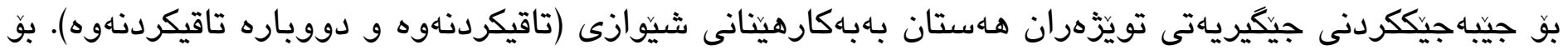

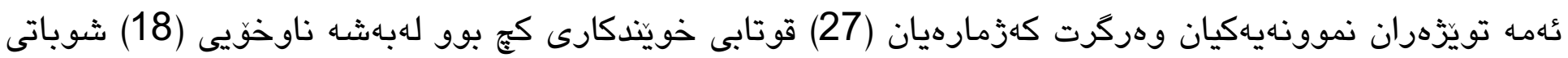

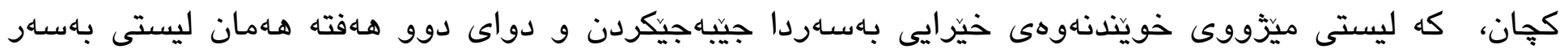

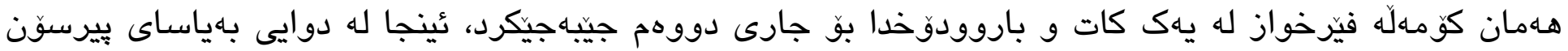

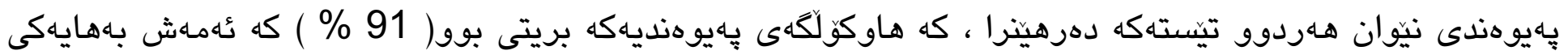

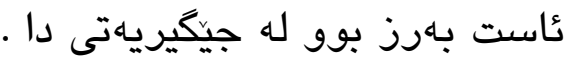




\section{3 جيّبهاجيكردنى بيّورومكه:}

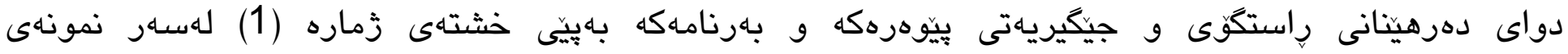

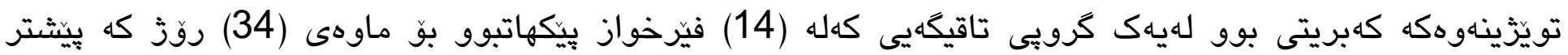

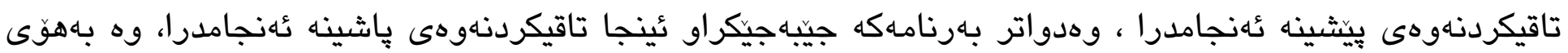

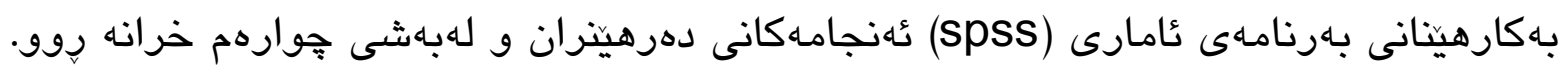

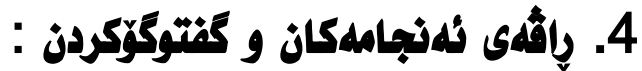

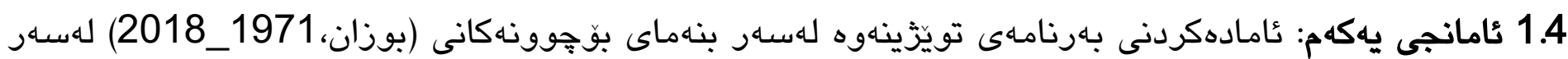

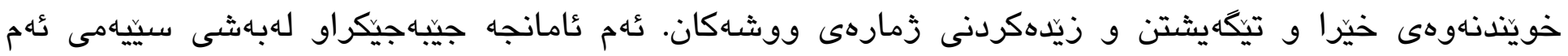
تويَزْينهوه يه ئامازَهى بِينكراوه.

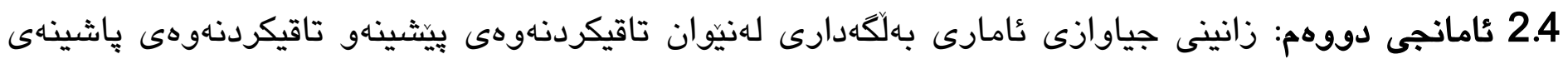
يهك كرويى تاقيكردناهوككه.

خشتهى (4) ئهنجامى تاقيكردنهوه تائى دوو نموونهى بهيوهست بهيهكهوه بوّتاقيكردنهوهى بيّشينهو هاشينه

\begin{tabular}{|c|c|c|c|c|c|c|c|}
\hline \multirow{2}{*}{ ثَاستى بـارى } & \multicolumn{2}{|c|}{ بههاى تائى } & \multirow{2}{*}{ نمرازى } & \multirow{2}{*}{ يلادانى } & \multirow{2}{*}{ ثَيَّهندهى } & \multirow{2}{*}{ نموونهك } & \multirow[t]{2}{*}{ كرويى تاقيكهيى } \\
\hline & خشتأئ & ذَميردراو & & & & & \\
\hline \multirow[b]{2}{*}{ بهالكَهداره } & & \multirow[t]{2}{*}{5.99} & 26 & $\begin{array}{r}57.8 \\
3\end{array}$ & 170.57 & 14 & تاقينيكردناهوهى \\
\hline & 3.373 & & 26 & $\begin{array}{r}166 . \\
84\end{array}$ & 441.64 & 14 & 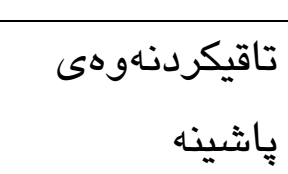 \\
\hline
\end{tabular}

بهييّى خشتهى زماره (4) دواي ئهنجامدانى تاقيكردنهوهى ئهزموونى كه (7) دانيشتنى له خوكرتبوو. هاوكات

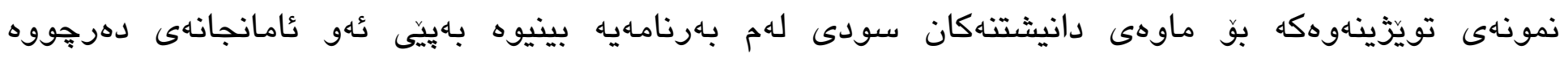


لهبهراوردكردنى تاقيكردنهوهى يِيشينه و ياشينهى كرويى تاقيكردنهوهدا . وه به بهكارهينانى ئامرازى ئامارى ( تائى

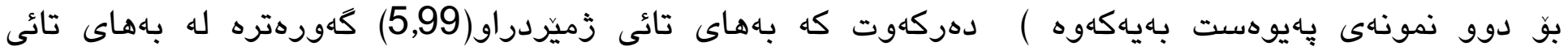

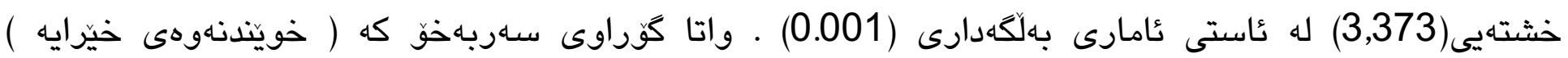

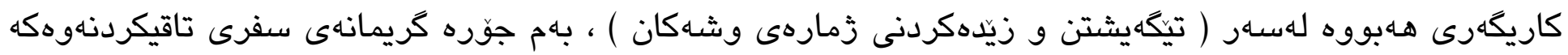

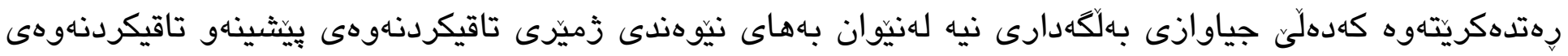

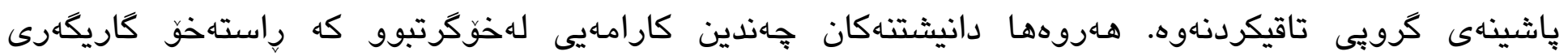

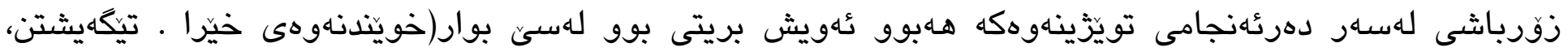

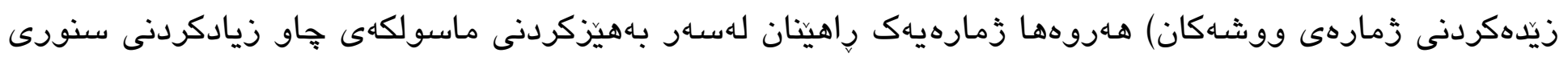

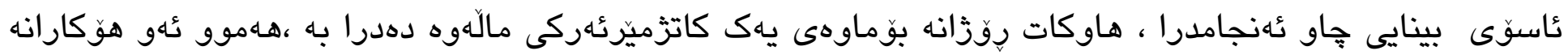
بووه هوَى ئهوهى نمونهى تاقيكردناهوكه دهرئهنجاميكى باش بهدهست بهينتى.

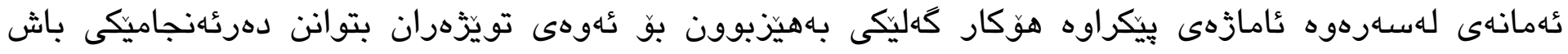

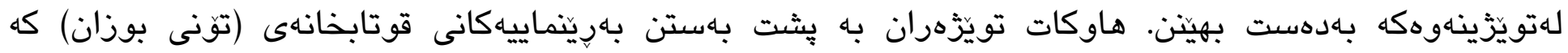

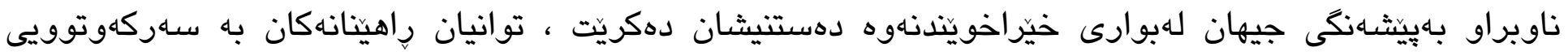

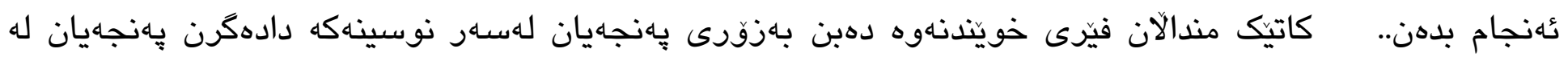

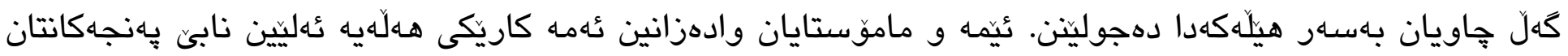

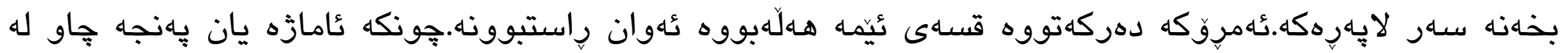

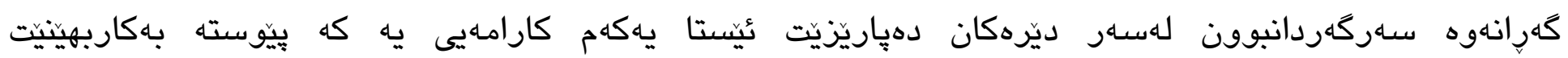

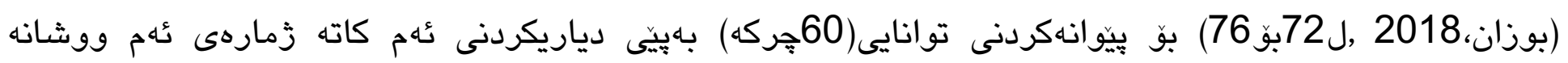
ديارى دهكهين كهلهم ماوهيهدا خوينّومانهتهوه يِّوسته ئهم كارامهيانهى خوارهوه ئهنجام بدريّن :

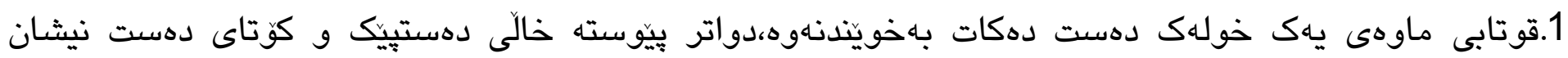

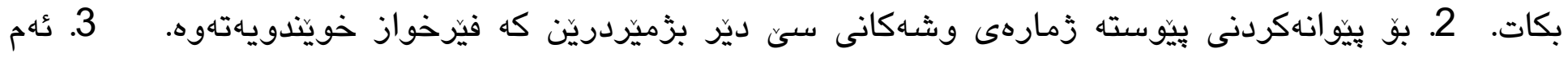

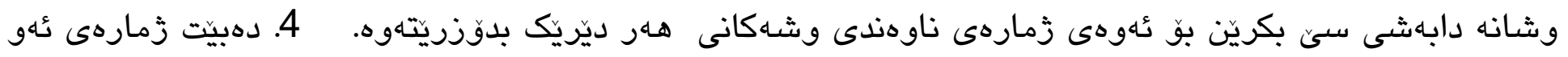

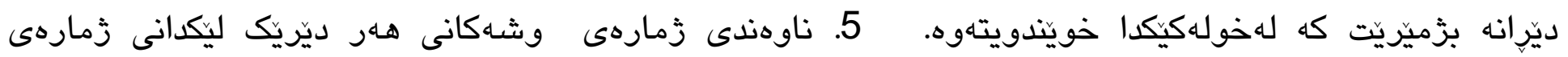
ديّرهكان بكهن ، تٔهو زمارهيه بهدهست ديّت كه يهكسانه به زمارهى تُهو وشانهى له ( 60 ) جركه خوينّاندويهتهوه.

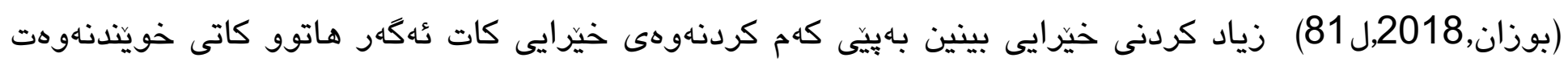
ريّكخست و دياريتكرد و دابهشتكرد بهسهر يهكهى كاتى كونجاو لهسهرهتاى دهستكردن بهخويندنهوه. ئهم ريّك

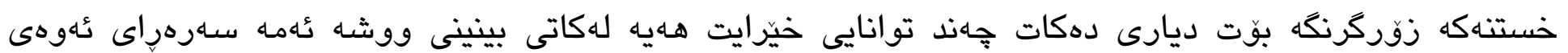
ورده وهرده تواناى يادهوهريشت فراوان دهكات. (بوزان،2012, ل136) 


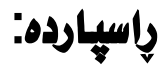

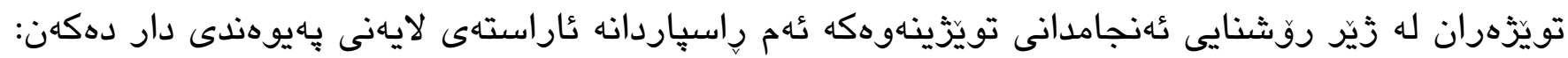

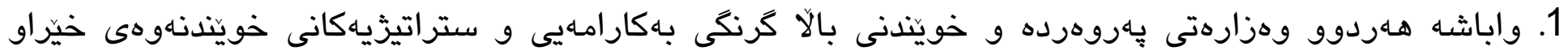

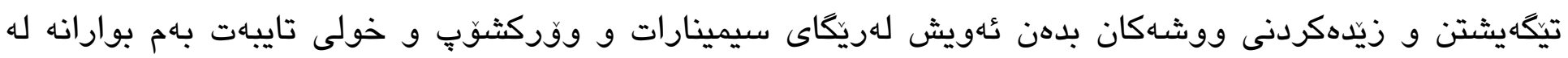

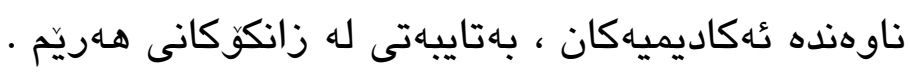

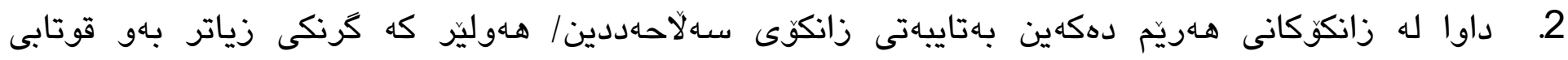

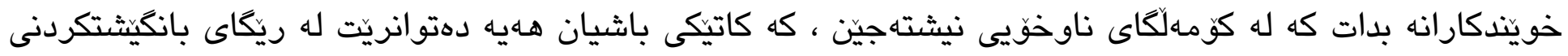

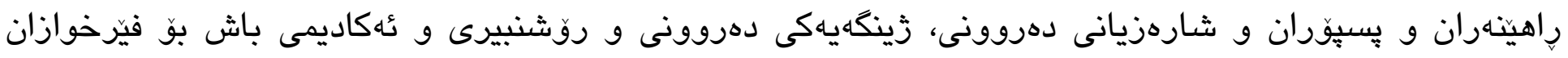

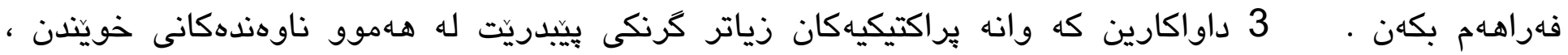

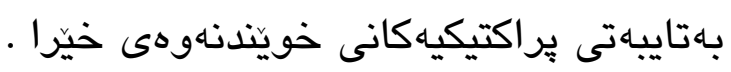

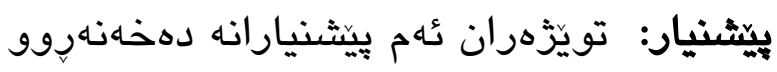

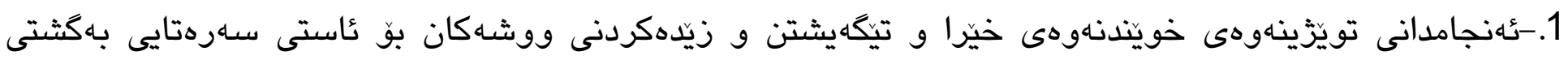
لهار فيرّخوازانى قوتابخانهكان ئهنجام بدريَت.

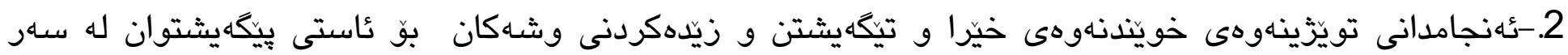

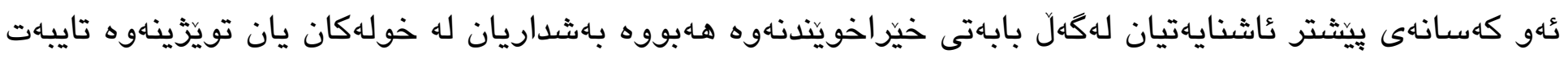
بهم بواره كردوه.

3.-ئهنجامدانى تويَّينهوهى خويندنهوهى وينّاهيى (فوتّق ريدينك) بوّ فيّرخوازانهى قوتابى ماستهر و دكتوران جونكه

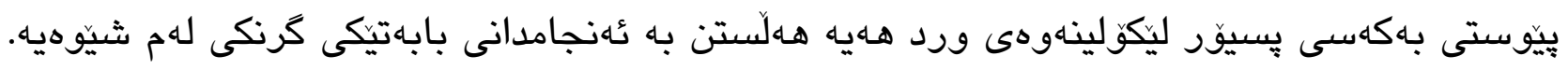




\title{
Speed Reading and its impact on Understanding and Increasing the number of words(experimental research)
}

\section{Moaid Ismail Jarjis}

Department of Educational and Psychological Counseling, College of Education, University of Salahaddin - Erbil, Kurdistan Region - Iraq.

E-mail: moaid.jarjis@su.edu.krd

\section{Bazyan Satar Khafur}

Department of Educational and Psychological Counseling, College of Education, University of Salahaddin - Erbil, Kurdistan Region - Iraq.

E-mail: bazyanbarznji10@gmail.com

\begin{abstract}
:
In the current empirical research, the researchers aimed to prepare a scale and program on rapid reading and its impact on understanding and increasing the number of words as it went (Tony Buzan, 2011 - 2018). The program was based on a sample consisting of (14) equal female students in terms of age, sex, social status and level of education, as one experimental group of students of the internal section (18) at the University of Salahaddin - Erbil. The importance of the current empirical research is that reading fast teaches students to learn new ways of reading and understanding and increasing the number of words, and left the previous misconceptions in reading and understanding, which we learned from childhood in schools, where it was an obstacle to reading fast and understanding and increase the number of words and benefit from the effort and time as well. The accuracy of the visual reliability and the stability of the method test and re-test were verified. The apparent of the visual reliability was $100 \%$ and the stability coefficient was $91 \%$. The pre-test was carried out on the experimental group and the program was applied to them and then the post-test was performed on them. Statistical analysis of the social sciences (Spss) showed the results: 1. Prepare a rapid reading program 2. There is a statistically significant difference between the arithmetic mean value of the pre- test and the post-test, in favor for the post-test in degree of freedom (26) at the level of statistical significance (0.001) This means that the independent variable (Quick Reading Program) has an effective effect on the dependent variables (understanding and increasing the number of words). In the light of the results, the researchers presented some recommendations and suggestions.
\end{abstract}

Key words: Speed Reading, Understanding \& increase the number of words, female students of the internal section (18) at the University of Salahaddin - Erbil. 


\section{القراعة السربعة وخأثيرها على الثهم وزيـادة عدد الكلمات ( بحث تجريبي) )}

مؤيل إسماعيل جرجيس

قسم الارشاد الزبويى و النفسي، كلية التربية، جامعة صلاح الدين- أربيل، اقليم كوردستان - العراق moaid.jarjis@su.edu.krd البريد الإلكتروني:

بازيـان ستار غفور

قسم الارشاد التربويى و النفسي ، كلية التزبية، جامعة صلاح الدين- أربيل، اقليم كوردستان - العراق bazyanbarznji10@gmail.com البريد الإلكتروني:

استهدف الباحثان في البحث التجريبي الحالي إعداد مقياس و برنامج حول القراءة السريعة وتأثيرها على الفهم وزيادة عدد الكلمات ، حسب ماذهب اليه (تونى بوزان،2011 - 2018) ـ وطبق البرنامج على عينة متكونة من (14) طالبة ( متكافئة من حيث العمر والجنس والحالة الإجتماعية والمستوى الدراسي) ، كمجموعة تجريبية واحدة من طالبات القسم الداخلي (18) شباط في جامعة صلاح الدين-/ أربيل. ويكمن أهمية البحث التجريبي الحالي في أن القرأة السريعة يعلم الطلبة على تعلم أساليب جلديدة للقراءة والفهم وزيادة عدد الكلمات، وترك الأساليب الخاطئة السابقة في القراءة والفهم والذي تعلمناها منذ الصفر في المدارس ، حيث كانت عائقا أمام القراءة السريعة والفهم وزيادة عدد الكلمات ـ بالإضافة الى الإستفادة من الجهد والوقت أيضا. وقد اعتمد الباحثان على إعداد مقياس للقراءة السريعة والفهم وزيادة عدد الكلمات. وقد تم التحقق من الصدق الظاهري والثبات بطريقة الإختبار وإعادة الإختبار، وكانت نسبة الصدق الظاهري هي (100٪) وقيمة معامل الثبات هي (91٪). وقد أجريت الإختبار القبلي على المجموعة التجريبية الواحدة , ثم تطبيق البرنامج عليهم ، ومن ثم أجريت الإختبار البعدي عليهم. ومعالجة البيانات إحصائيا بإستخدام الحقيبة الإحصائية للعلوم الإجتماعية (SpSS) أظهرت النتائج : 1. إعداد برنامج للقرأة السريعة 2. وجود فرق دال إحصائيا بين قيمة المتوسط الحسابي للإختبارالقبلي والإختبار البعدي، لصالح الإختبار البعدي بلدرجة الحرية (26) عند مستوى الدلالة الإحصائية (0,001) وهذا يعني بأن المتفير المستقل (برنامهج القراءة السريعة) ذو تأثير فعال على متفيري التابع (الفهم وزيادة عدد الكلمات) . وفي ضوء النتائج قدم الباحثان بعض التوصيات والمقترحات.

الكالمات اللارالة القراءة السريعة , الفه وزيادة عدد الكلمات , طالبات القسم الداخلي 18 شباط في جامعة صلاح الدين-أربيل. 
أبو عكر ,محمد(2014) برنامج قرائى حاسوبي لنتميه مهارتي السرعة والفهم لدى تلاميذ المرحله الاعداديه (رساله دكثوراه غير منشوره).جامعه قناه السويس ،الاسماعليه أبو علام،رجاع(2010) مناهج البحث فى العلوم النفسيه والتربويه،القاهيره دار النشرللجامعات.

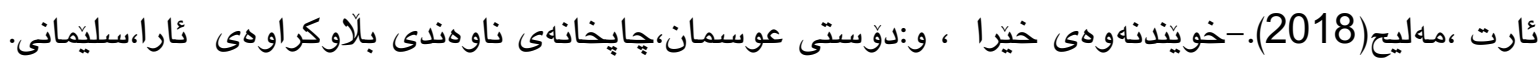

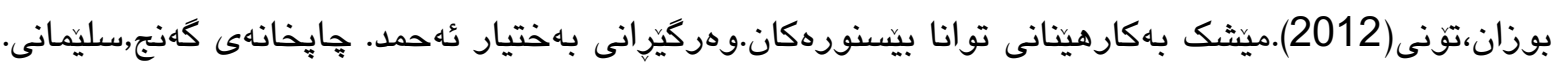

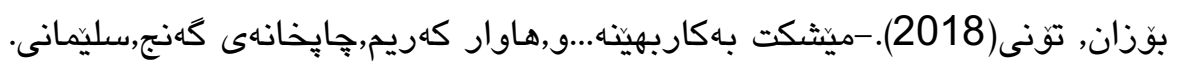

البرقعاوي,جلال عزيز فرمان وأحمد,حامد شهاب(2016).فاعلية مهارات القراءة السريعة لمادة المطالعة في الفهم القرائي عند طلاب

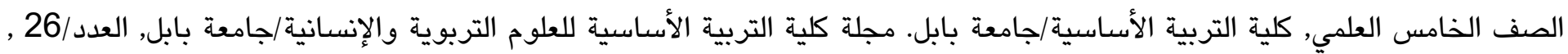
نيسان/ 2016. وود,إفلين (2009). مهارات القراءة السريعة. ترجمة: هند رشدي . القاهرة .كنوز للنشر والتوزيع. يونس، فتحي(2001). استراتيجيات تعليم اللغة العربيةفي المرحلة الثانوية, مطبعة الكتاب الحديث, القاهرة.

المصري،هالة اسماعيل(2017) فعاليه برنامج الكترونى لتنمية مهارتى السرعة والفهم القرائى لدى تلميذات الصف الرابع الآساسي بغزه، في كليه التربيه،جامعة الإسلامية بغزة رساله ماجستيرغير منشورة.

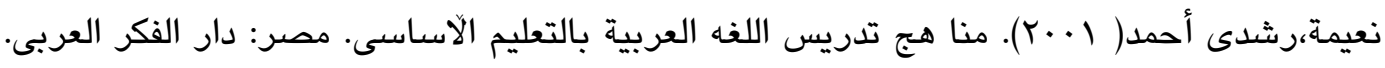


السيد, فؤاد البهي (1979).علم النفس الإحصائي وقياس العقل البشري. ط3,دار الفكر العربي.

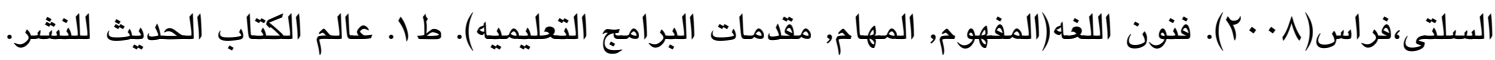

سلام،على.(2004).استراتيجيات استيعاب المقروء لدى القارئ العربي وعلاقتها بكل من المستوى التعليمي والجنس ونوع النص.

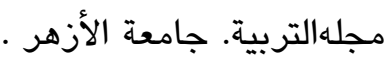

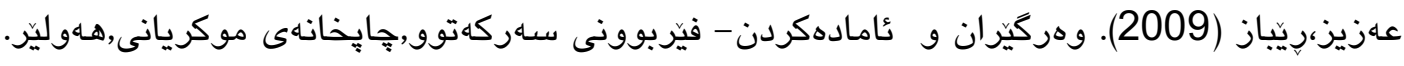

عبدالحميد، أيمن(2015).فعالية استراتيجية التعليم المباشرفي تنمية بعض مهارات الفهم القرائي لتلاميذ ذوي صعوبات التعليم. مجلة التربية الخاصة والتأهيل مؤسسة التربية والتأهيل المصري.

• عبدالرحمن , هدى (2003). إستراتيجيات الفهم القرائي لدى طلاب الجامعة وعلاقتها بإهتمام القرائي .كلية التربية , جامعة جنوب الوادي بسوهاج.

الثديفات،اثجان و أبو النادى.(2017).اثر استخدام استراتيجيه خرائط المفاهيم فى تنمية مهارات الفهم القرائي ابداعي لدى تلاميذ الصف السادس الابتدائى فى المملكة العربيه السعودية،ونجله كليه التربية جامعة بنه.

شينفرد، بيتر وميشيل ،جريجوري(2006). القراءة السريعة, ترجمة : احمد هوشان.

شحاتة,حسن والنجار,زينب (2003). معجم المصطلحات التربوية والنفسية.ط1 , مصر : الدار اللبنانية للنشر والتوزيع ·

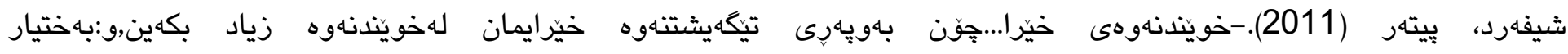
ئه حمهد,جإِخانهى كَنج,سليَمانى. 
الشرقاوي, محمود(2009). أسرار القراءة السريعة, ط1 ,دار أجيال للنشر , القاهرة .

Alarfaj,Abeer.\& Alshumaimeri, Yousif (2011). The effect of a suggested training program on reading speed and comprehension of Saudi female university students Procedia - Social and Behavioral Sciences 31 (2012) $612-628$

Buzan , Tony. (1971). The Speed Reading Book . published by BBC Worldwide Limited.

Rayner,Keith. \& et al (2016). So Much to Read, so Little Time: How Do We Read, and Can Speed Reading Help Psychological Science in the public Interest (Volume 11,Number 1 ), first published January 14. 2016.

Snow,Catherine E.(2002).Reading for understanding:toward a research and developmen .

program in reading comprehension.the office of Education Research and Improvement (OERI), U.S. Department of Education.

Suzanne,Sackstein.\& et al(2015). Are e-books effective tools for learning? Reading speed and comprehension: iPad®i vs. paper. South African Journal of Education, Volume 35, Number 4, November 2015.

Wallot,Sebastian. \& et al (2014). The Role of Reading Time Complexity and Reading Speed in Text Comprehension. Journal of Experimental Psychology, Learning, Memory, and Cognition, 2014, Vol. 40, No. 6, 1745-1765. 
هاشكوى (1) ناوى شارهزايانى بيّوهرى خيّرايى خويتدنهوه و بهرنامهكه.

\begin{tabular}{|c|c|c|c|}
\hline شوينى كار & ناوى سيانى & نازناوى زانستى & $\dot{j}$ \\
\hline كوليّزى بهاروهرده زانكوى & محمد محى الدين صادق & يَّروفيسوَرى & 1 \\
\hline 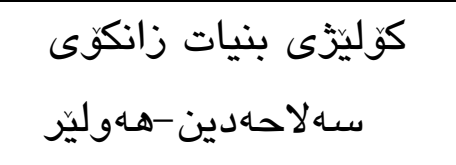 & د.فهرهاد على & 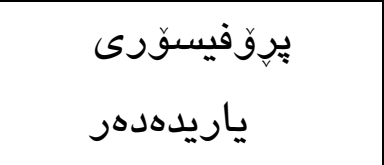 & 2 \\
\hline كوليزّى سُاداب زانكوىى & د.ريّزان على أبراهيم & 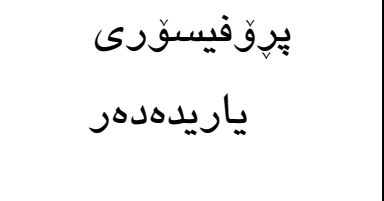 & 3 \\
\hline كوليزّى بنيات زانكوَى لاحهدين -هـهوليزر & د.ئاراس حهكيم رهزا & ماموّستا & 4 \\
\hline كوليزّى بنيات زانكوَى & د.دارا مشير ئيبراهيم & ماموّستا & 5 \\
\hline كوليزّى بنيات زانكوّى & جيران سـاباح عبدولا & ماموّستاى ياريدهدهر & 6 \\
\hline كوليَزى بنيات زانكوَى & نهوزاد ئيسماعيل حوسينّ & ماموّستاى ياريدهدهر & 7 \\
\hline
\end{tabular}




\title{
(2) بְاشكوى زماره)
}

\author{
زانكوى سـه لاحهدين -هـهوليّر \\ كوليَزَى يهروهرده
}

بهاشى ريّنماى يَروهردهيى و دهروونى

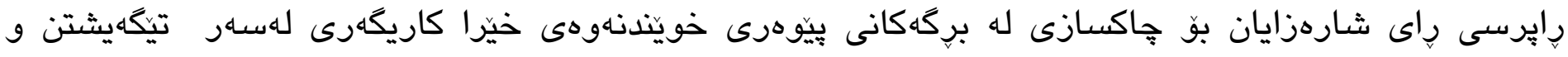

$$
\text { زيّدهردنى زمارهى ووشـهكان. }
$$

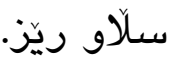

ماموَستاى بـاريَز...

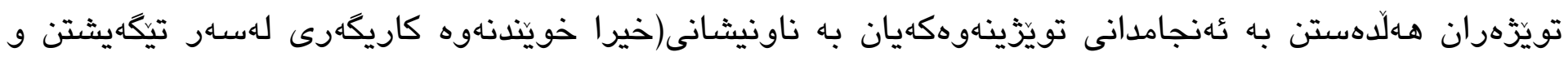

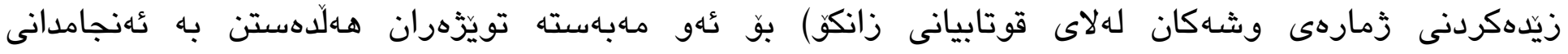
تويّزينهوهكهيان به شيّوازى تاقيكَهيى(خويندنهوهى خيّرا له ماوهى يهك خولهك و بهرهوه خواروو بهره بـره)

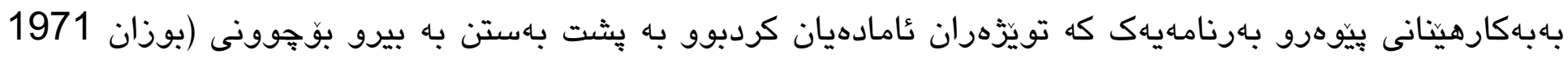

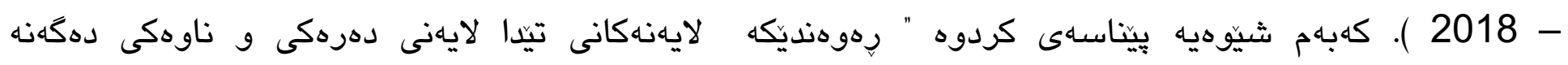
هاوسـانكى, بهتايبهت له ناسين و كيثنكردن تيك بـاهتن و بهياد سياردن و بهاياد هينانهوه. " دواى سـرنجدان كه

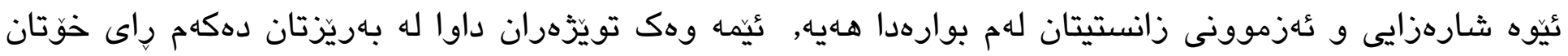

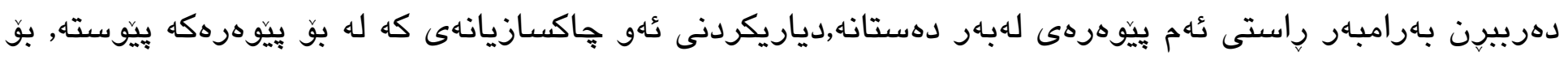

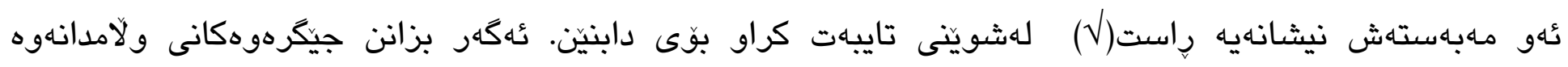

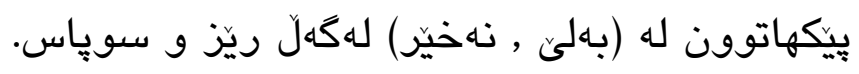

\begin{tabular}{|c|c|c|c|}
\hline نهخيّر & بهلّي & لايهنهكانى بركهكان & ز زماره \\
\hline & & 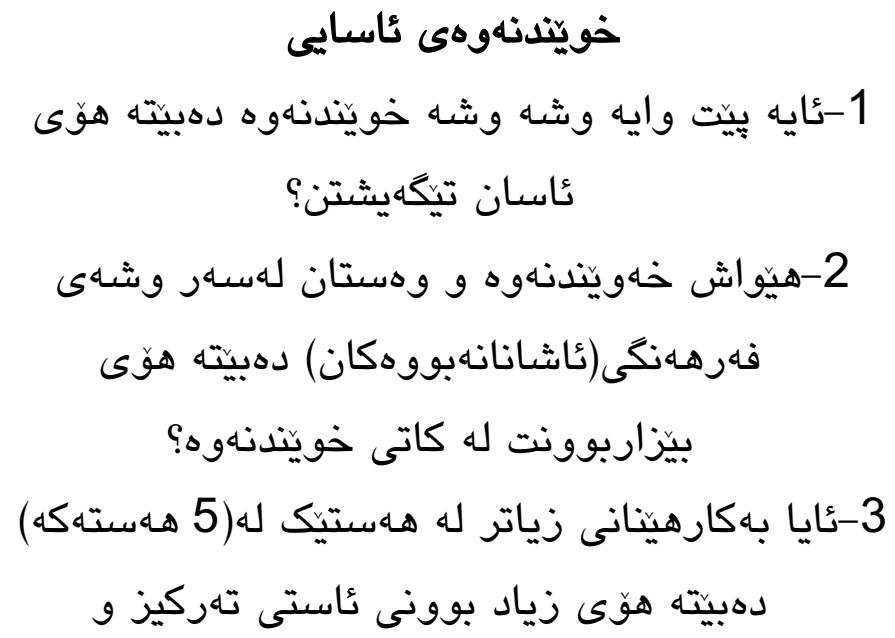 & 1 \\
\hline
\end{tabular}




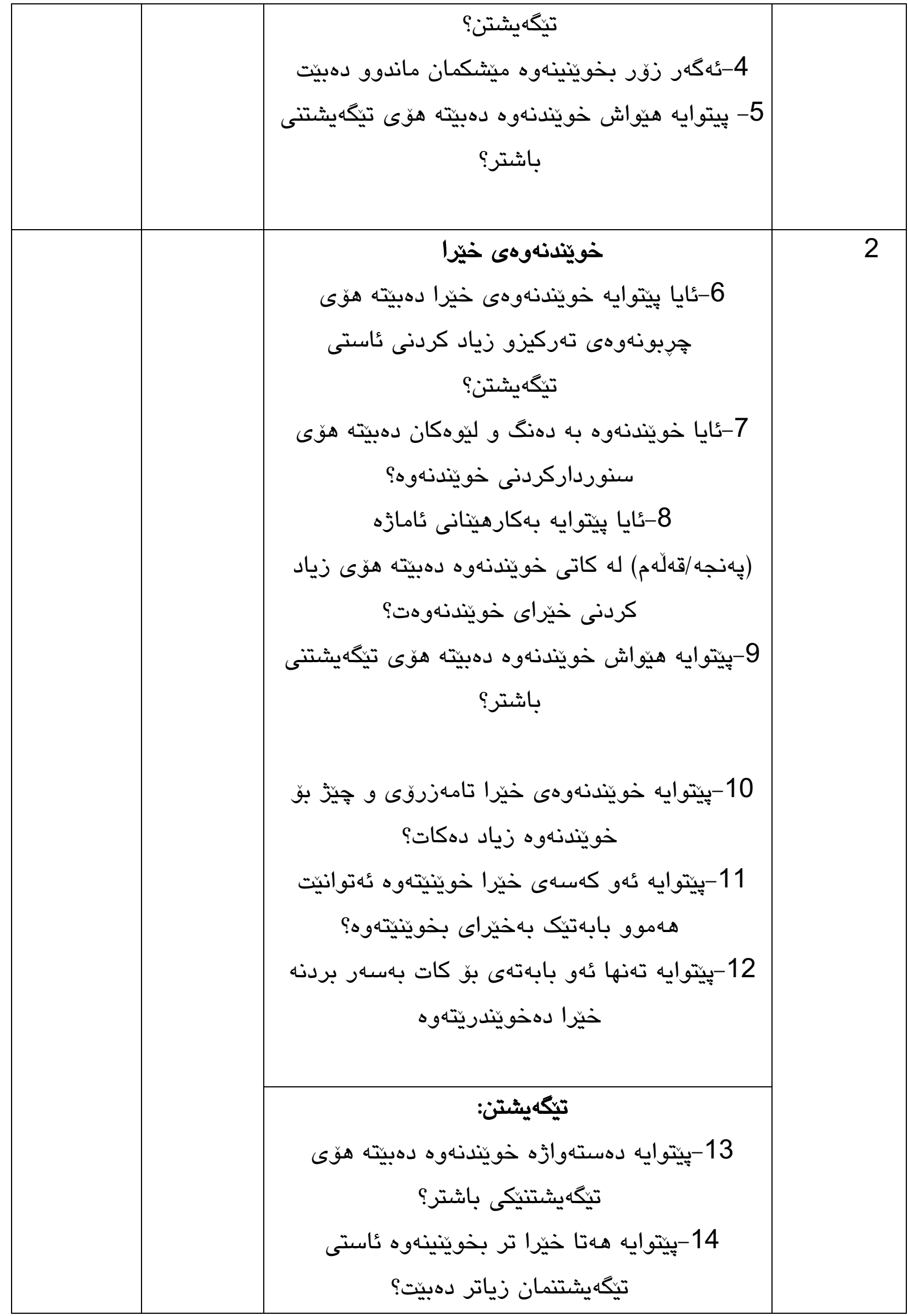




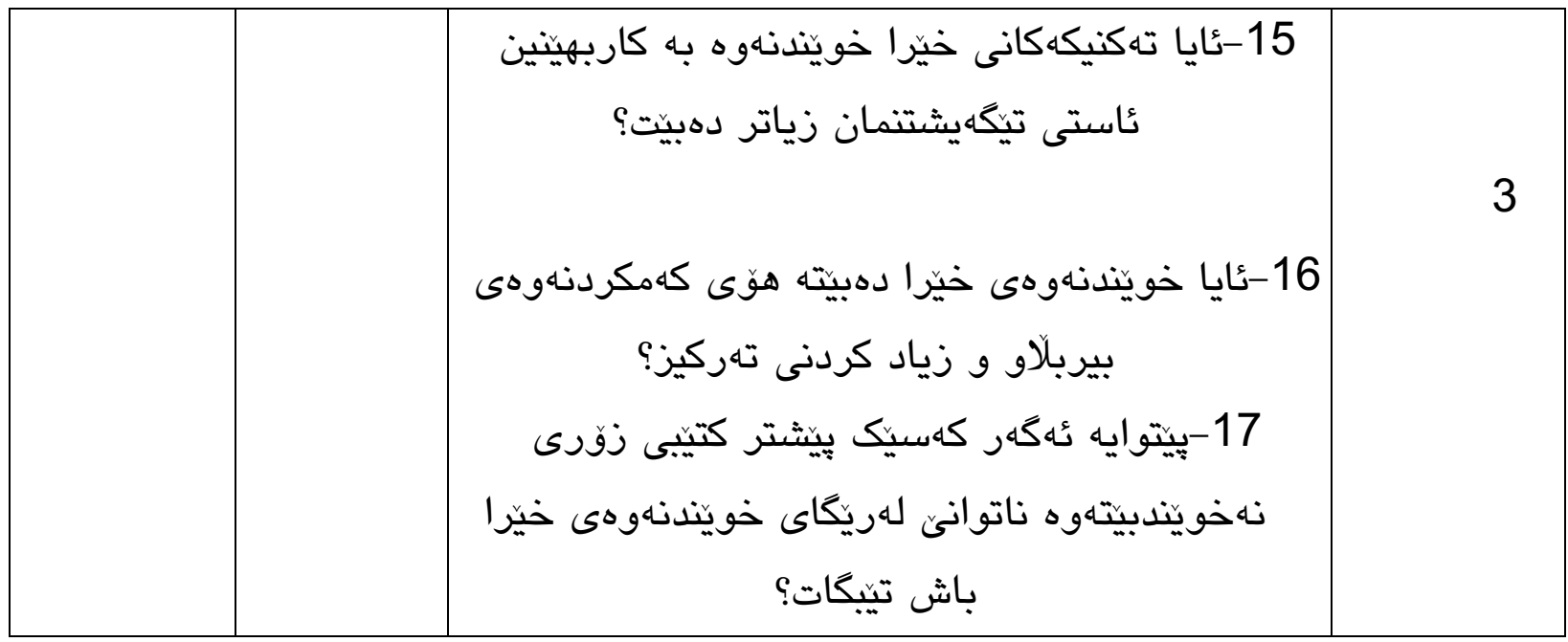

ميّزوووى خيّرا خويندنهوه : (دهقى نوسراوى تاقيكردنهوهى تاقيكهيى ، كهبق خوينّنهوهى خيّرا بهكارهاتووه ) :-

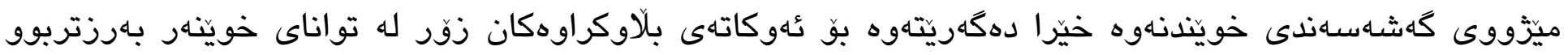

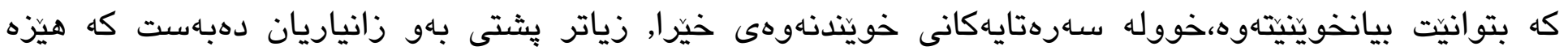

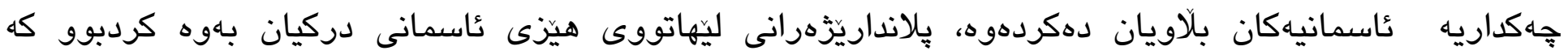

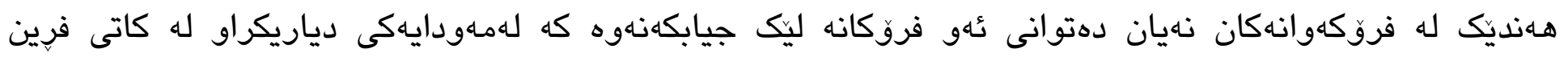

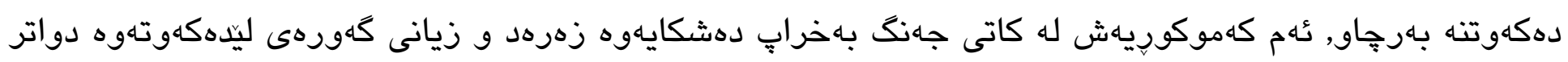

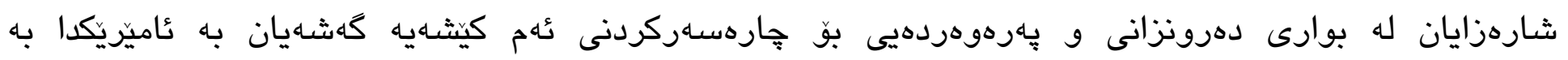

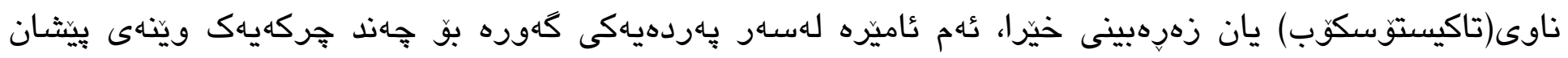

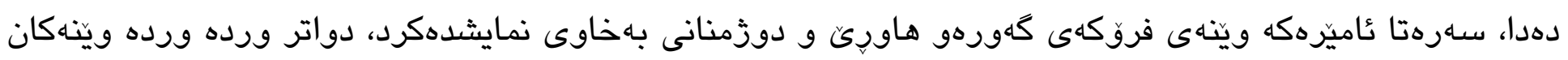

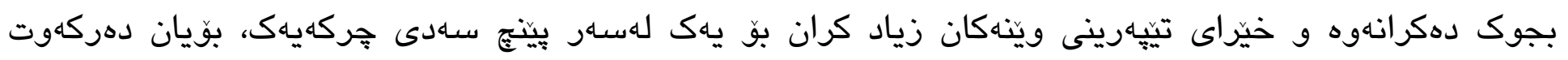

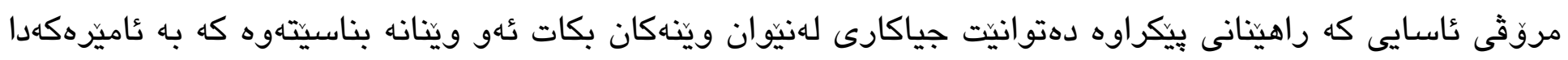

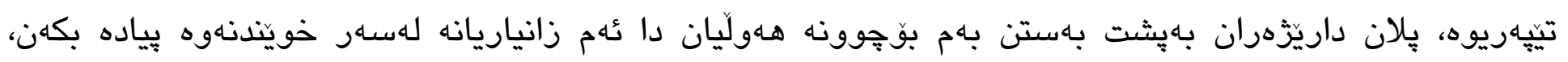

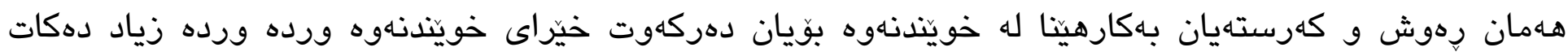

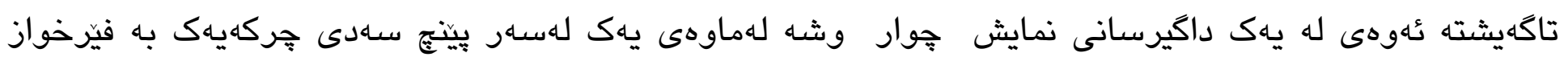

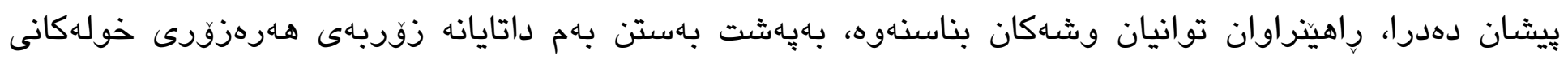

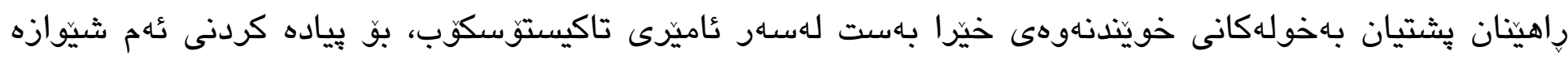

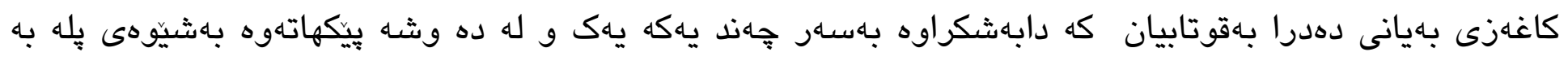


يله ل له(100) وشـوه دهكاته (400) ووشه له خولهكيكدا، زوربوى فيرّخوازان توانيان له خولهكيكدا خيرايان له

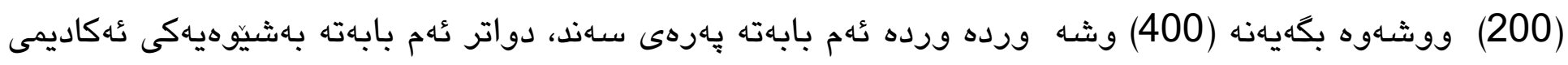

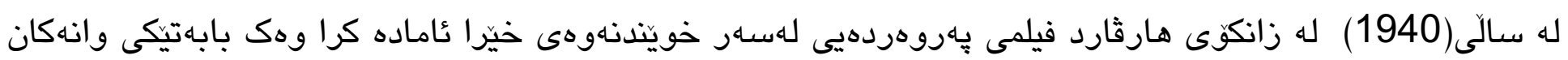

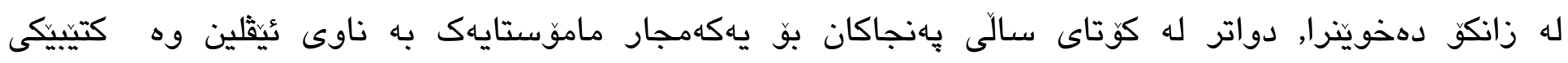

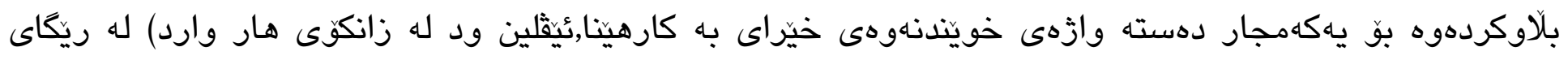

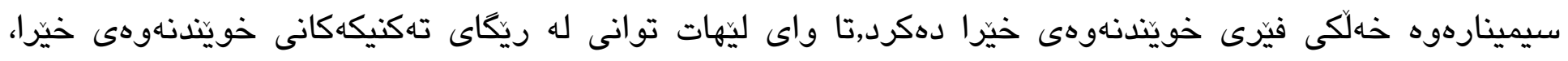

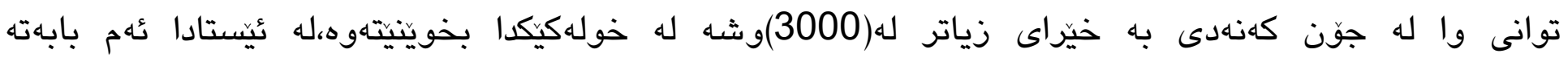

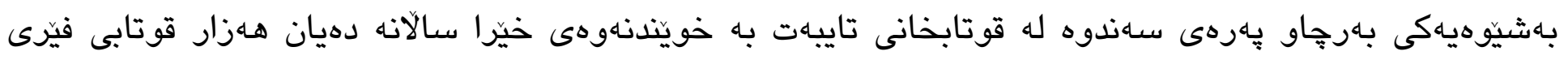
تهكنيكهكانى خوينتدنهوهى خيّرا دهكريَن. 